\title{
Enflasyon Hedeflemesi Rejiminde Para Politikasının Analizi: Türkiye İçin Dinamik Stokastik Genel Denge Modeli Tahmini*
}

\author{
The Analysis of Monetary Policy in the Inflation Targeting Regime: \\ An Estimated DSGE Model For Turkey
}

\author{
Yrd. Doç. Dr. Bilgin Bari - Prof.Dr. ilyas Şıklar
}

\begin{abstract}
Öz
Dinamik stokastik genel denge(DSGD) modelleri son yıllarda para politikası analizlerinde yaygin bir şekilde kullanılmaktadır. Bu çalışmada da dışa açık küçük ekonomi DSGD modeli Türkiye için tahmin edilmektedir. Model nominal ve reel katıliklar, eksik rekabet ve tüketicinin fayda fonksiyonunda alışkanlik oluşturma özelliklerine sahiptir. Daha sonra Yeni Keynesyen makroekonomik çerçeve kapsaminda optimum para politikası ele alınmaktadır. Model 2002:Ç1 - 2012:Ç4 dönemi için Bayesci yöntem kullanılarak tahmin edilmektedir. Bu yöntemde önsel ve olabilirlik fonksiyonu yapısal parametrelerin sonsal dağılımlarını elde etmek için birlikte kullanılmaktadır. Sonuçlar parasal otoritenin enflasyona güçlü bir şekilde tepki verirken çıktı açı̆̆ına zayıf tepki verdiğini göstermektedir.
\end{abstract}

Anahtar Kelimeler: Dinamik Stokastik Genel Denge Modeli, Optimum Para Politikast, Yeni Keynesyen Model, Bayesci Yaklaşım

\begin{abstract}
Dynamic Stochastic General Equilibrium (DSGE) models have been widely used for monetary policy analysis in recent years. In this study, a small open economy DSGE model are estimated for Turkey. The model features nominal and real rigidities, imperfect competition
\end{abstract}

and habit formation in the consumer's utility function. Later optimal monetary policy is explained in detail in the New Keynesian macroeconomic framework. The model is estimated using by Bayesian methods for the period 2002:Q1 - 2012:Q4. The parameter estimates shows that monetary authority reacts to inflation robustly while it reacts to the output gap weakly.

Keywords: Dynamic Stochastic General Equilibrium Model, Optimal Monetary Policy, New Keynesian Model, Bayesian Approach

\section{Giriş}

$\mathrm{Bu}$ çalışmanın amacı 2002-2012 yılları arasında Türkiyede uygulanan para politikasının etkinliğini analiz etmektir. Ele alınan dönem Türkiye ekonomisinde yaşanan derin kriz sonrası iktisat politikasında önemli değişikliklere gidilen bir dönemdir. Bu önemli değişikliklerden biri de para politikasının enflasyon hedeflemesi rejimi çerçevesinde yürütülmeye başlanmasıdır.

Türkiyede uygulanan enflasyon hedeflemesi rejimini örtük enflasyon hedeflemesi dönemi (2002-2005), açı enflasyon hedeflemesi dönemi (2006-2010) ve küresel kriz sonrası dönem (2011'den günümüze)

\footnotetext{
Yrd. Doç. Dr. Bilgin Bari, Anadolu Üniversitesi İİBF, bbari@anadolu.edu.tr Prof.Dr. İlyas Şılar, Anadolu Üniversitesi İİBF, isiklar@anadolu.edu.tr

* Bu çalışma Bilgin Bari’nin Anadolu Üniversitesi Sosyal Bilimler Enstitüsü İktisat Ana Bilim Dalında Doktora Tezi olarak kabul edilen "Yeni Keynesyen Modelde Optimum Para Politikası: Türkiye İçin Dinamik Stokastik Genel Denge Modeli" isimli çalışmadan üretilmiştir.
} 
olarak üç bölüme ayırabiliriz. Bu çalışmada enflasyon hedeflemesi rejimi dönemi Yeni Keynesyen makroekonomik çerçeve içerisinde incelenmektedir. Yeni Keynesyen model ekonomideki konjonktürel dalgalanmaların açıklamasında bir önceki model olan Reel İş Çevrimleri modelinin tersine parayı ve parasal otoritenin kararlarını makroeokonmik yapıya dahil etmekte ve tam rekabetçi piyasalar varsayımını terk edip fiyat katılıklarına odaklanmaktadır. Nominal katılıklar, yapışkan fiyat ve ücret ile modele dahil edilerek para politikasının reel değişkenleri etkileyeceği savunulmaktadır.

Kydland ve Prescott'un 1982 yılında yaptıkları çalışmaları makroiktisat teorisi ve makroekonomik modelleme açısından önemli bir dönüşümün başlangıcı kabul edilmektedir. İktisat teorisine katkılarıyla Nobel İktisat ödülü sahibi de olan iktisatçılar bu çalışmalarında Amerikan ekonomisini modellemişler ve Reel İş Çevrimleri (RİÇ) modelini iktisat literatürüne kazandırmışlardır. Dinamik stokastik genel denge (DSGD) modelinin bir alt türü olan RİÇ modeli ekonominin reel tarafına odaklanmakta ve parasal kısım modelde gözardı edilmektedir. Model esnek fiyatlar altındaki bir ekonomide iş çevrim dalgalanmalarını açıklamada bazı reel şokları (teknoloji, verimlilik vb.) ve stokastik büyüme modelini birlikte kullanmaktadır. Yeni Keynesyen iktisatçılar bu modelin varsayımlarını değiştirmiş ve modele para politikasının etkilerini dahil ederek başka bir DSGD modeli geliştirmişlerdir.

DSGD modelleri politika analizi için tutarlı bir çerçeve sağlayan güçlü araçlardır. Bu modeller ekonomideki dalgalanmaların kaynaklarını belirlemede yardımcı olabilir, yapısal değişimlerin nedenlerini açıklayabilir, politika değişimlerinin etkilerini tahmin edebilir ve karşılgusal (counterfactual) deneyleri uygulamayı kolaylaştırabilirler ${ }^{1}$. Bu modeller ayrıca geniş ölçekli modellerde her zaman mümkün olmayan indirgenmiş form parametreleri ve ekonominin yapısal özellikleri arasında bir ilişki kurmayı da sağlamaktadır.

1 Burada karşılolgusal deneyler ile modelin simülasyon teknikleri yardımıyla olmayan durumları da analiz edebilme özelliği vurgulanmaktadır.
DSGD modelinin temel özellikleri modelin ismi ile açılanabilir. Modelin dinamik yapısı değişkenlerin zaman içerisindeki hareketlere odaklanması sonucu ortaya çıkmaktadır. Burada değişkenin cari değerinin yanısıra geçmiş ve gelecek değerleri de dikkate alınmaktadır. Model zaman içerisinde hareket eden dinamik ekonomiyi rassal şoklara açık hale getirdiği için de stokastik özelliğe sahip olmaktadır. Model ekonomiyi bir bütün olarak ele alıp incelemektedir. Modelin politik olmayan bloğu olarak adlandırılan kısmında ekonominin genel dengesi mikroekonomik birimlerin (hanehalkı ve firmalar) davranışsal denklemlerinden elde edilen arz ve talep denklemleriyle gösterilmektedir. Modelin politik bloğunda ise çıktı ve fiyat istikrarı tercihlerine göre hareket eden merkez bankasının politika aracının kullanımı gösteren faiz oranı kuralı yer almaktadır.

Çalışmanın ikinci bölümünde DSGD modelinin elde edilişi dişa açık bir ekonomi için açılanmaktadır. Üçüncü bölüm optimum para politikasını ele almaktadır. Dördüncü bölümde Bayesci tahmin yöntemi özetlenmekte ve tahmin sonuçları değerlendirilmektedir. Son bölüm ise ampirik bulguların yorumland1ğı çalışmanın sonuç kısmıdır.

\section{Modelin Yapısı}

Burada olușturulan dıșa açık küçük ekonomi modeli, Gali ve Monacelli (2005), Gali (2008), Liu (2006) ve Lubik ve Schorfheide (2005)'nn geliştirdikleri modeller temel alınarak oluşturulmuştur. Modeli basit hale getirmek ve ekonominin dışa açıklığına bağlı olarak oluşan durumlara odaklanmak için maliyet-itişli şokların veya nominal ücret katılıklarının olası varlığı ihmal edilmektedir. Calvo fiyat belirleme modeli ve tam finansal piyasalar varsayımı ile birleştirilmiş teknoloji ve tercihler üzerindeki varsayımlar, basit ve sezgisel logaritmik-doğrusal hale getirilmiş denge koşulları ve daha anlaşılabilir bir model elde etmemizi sağlamaktadır. Bu oldukça basit ve sezgisel logaritmik-doğrusal denge koşulları Yeni Keynesyen Phillips eğrisi ve dinamik IS denklemlerini içeren iki denklemli dinamik sisteme indirgenebilir ${ }^{2}$. Bu iki denklem para politikasının nasıl yönetildiğinin tanımı ile tamamlanmaktadır.

2 Sayfa kısıtı nedeniyle ilgili genel denge denklemlerinin elde edilişi burada yer almamaktadır. İlgilenenler yazar ile iletişime geçebilirler. 


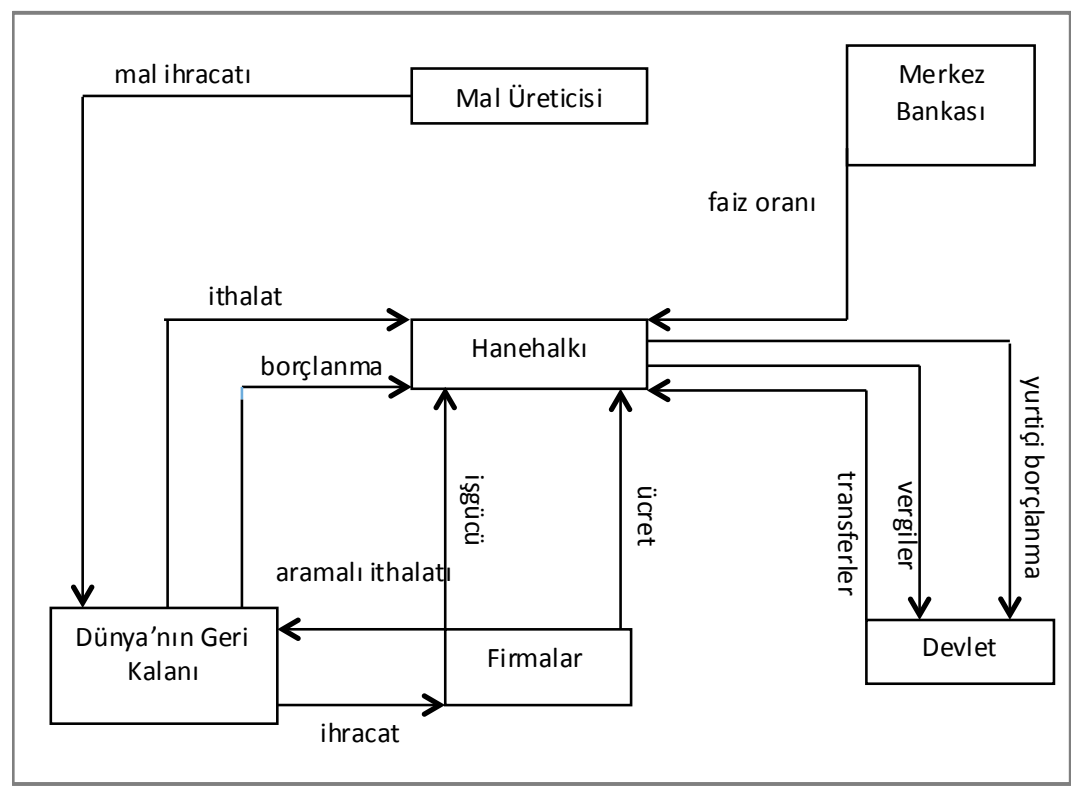

Kaynak: Strom ve Poghosyan, 2011:6

Şekil 1. Dışa Açık Ekonominin Akım Şeması

\section{Genel Denge}

\section{Geleneksel Gösterim}

$\mathrm{Bu}$ bölümde dişa açık küçük bir ekonomi için doğrusal hale dönüştürülmüş denge dinamikleri ele alınmaktadır. Yurtiçi enflasyon ve çıktı açı̆̆ı eşitlikleri elde edilmektedir.

Çıktı açığı aynı şekilde $\tilde{y}_{t} \equiv y_{t}-y_{t}^{n}$ olarak tanımlanmaktadır. Yurtiçi reel marjinal maliyet ve çıktı açı̆̆ı ilişkisi aşağıdaki şekilde ortaya çıkar:

$$
\widehat{m c}_{t}=\left(\sigma_{\alpha}+\varphi\right) \tilde{y}_{t}
$$

Yeni Keynesyen Phillips eğrisi dışa açık ekonomi için aşağıdaki şekilde elde edilmektedir:

$\pi_{H, t}=\beta E_{t}\left\{\pi_{H, t+1}\right\}+\kappa_{\alpha} \tilde{y}_{t}$

(2.2)'de $\kappa_{\alpha} \equiv \lambda\left(\sigma_{\alpha}+\varphi\right)$ ve $\alpha=0$ (veya $\sigma=\eta=\gamma=1$

) için eğim katsayısı $\lambda(\sigma+\varphi)$ tarafından verilmekte-

dir. Dışa açık ekonomi için enflasyon eşitliği yurtiçi enflasyon ile ilgilidir. Dışa açıklığın derecesi $(\alpha)$ sadece Yeni Keynesyen Phillips eğrisinin eğimi üzerindeki etkisi yoluyla enflasyon dinamiklerini etkilemektedir. Eğim üzerindeki etkisi ise çıktı açığındaki değişmelere enflasyonun tepkisinin büyüklüğüne bağlı olmaktadır.
Euler denklemlerini kullanarak dışa açık ekonomi için dinamik IS denklemini çıktı açığı cinsinden ifade edebiliriz:

$\tilde{y}_{t}=E_{t}\left\{\tilde{y}_{t+1}\right\}-\frac{1}{\sigma_{\alpha}}\left(i_{t}-E_{t}\left\{\pi_{H, t+1}\right\}-r_{t}^{n}\right)$

(2.3)'de $r_{t}^{n}$ dışa açık küçük ekonomi için doğal faiz oranı olmaktadır.

Dışa açık küçük ekonomi için bulduğumuz ileriye dönük IS eğrisi iki çıkarıma sahiptir. Birincisi, dışa açıklığın derecesi faiz oranındaki değişmelere çıktı açığının hassasiyetini etkilemektedir. İkincisi ise dışa açıklık nedeniyle doğal faiz oranı yurtiçi verimliliğin yanı sıra beklenen dünya çıktı büyümesine de bağlı olmaktadır (Gali, 2008b, s.165).

\section{Optimum Para Politikası}

Yeni Keynesyen modelde para politikası bir bilim olarak görülmektedir. Bunda para politikasının yürütülmesinin basit ve sağlam kurallara dayandırılması önemli bir etkiye sahiptir (Blanchard, 2006, s. 1). Bu bölümde, Yeni Keynesyen makroekonomik çerçeve kullanılarak para politikası nasıl yönetilmeli sorusu ele alınacaktır. Burada amaç optimum (en uygun) 
para politikasını bulmaktır. Optimum para politikası ekonomideki mevcut kısitlar altında iktisadi ajanların refahını maksimum yapan politikadır. Optimum para politikasının merkezinde ise enflasyon hedeflemesi rejimi yer almaktadır. Bir başka ifadeyle, para politikasının temel amacı fiyat istikrarı olmaktadır.

Enflasyon hedeflemesi uygulanırken merkez bankası enflasyon hedefine ulaşmak için politikasını üç sacayağına dayandırmalıdır (Walsh, 2001, s. 13): (1) çıktı açığına odaklanmak, (2) faiz kuralını takip etmek, (3) ileriye dönük hareket etmek.

Çıktının denge düzeyinden sapması anlamına gelen çıktı açığı enflasyondaki değişimlerin temel sebeplerinin başında gelmesi nedeniyle önem taşımaktadır. Merkez bankası, cari çıktı ve potansiyel çıktı arasındaki açı̆̆ı birbirine yakın tutmaya çalışır. Merkez bankası çıtıyı potansiyel düzeyinin üzerinde tutmak için genişleyici politika uyguladığında enflasyon daha yüksek gerçekleşecektir. Bu nedenle merkez bankası çıktı açı̆̆ında istikrarı gözetmelidir. Bir başka ifadeyle, çıtı potansiyel (tam istihdam) düzeyine yakın tutulmalıdır (Svensson, 1999, s. 210).

İkinci temel prensip merkez bankasının bir faiz kuralını takip etmesi gerektiğidir. Burada kural ile kastedilen bir tepki fonksiyonudur. Bu tepki fonksiyonu para politikası uygulamasında faiz oranının davranışını ifade etmelidir (Allsop ve Vines, 2000, s. 17). Burada enflasyondaki artışa faiz oranının göstereceği tepki, enflasyondaki artıştan daha fazla olmalıdır. Böylece reel faiz oranı toplam talep üzerinde etkili olabilecektir. Uygulamada sıkça kullanılan faiz oranı kuralı Taylor kuralıdır.

Para politikasının uygulanmasında önce amaçlar belirlenmekte sonra uygulama ile ilgili konular ele alınmaktadır. Bunun için öncelikle optimum politikada uygulanan faiz oranı kuralları elde edilmektedir. Pratikte bu kurallar para politikasina tam olarak yol gösterici özelliğe sahip değildir. Bütün hepsi merkez bankasının bir değişkendeki (bu değişken nominal faiz oranı olmaktadır) değişmelere eşzamanlı olarak tepki vermesini gerektirmektedir.

Enflasyon hedeflemesi rejiminde para politikası aracı kısa vadeli faiz oranlarıdır. Merkez bankası önce politika faizi adı da verilen bu faiz oranını belirlemekte daha sonra koridor sisteminde bu faiz oranının ekonomi için referans faiz haline gelmesini sağlamaktadır. Bu faiz oranı ise parasal aktarım mekanizması yoluyla çıktı üzerinde etkili olmaktadır.

\section{Merkez Bankası ve Faiz Oranı Kuralı}

Optimum para politikası teorisinin temel sorunu para politikasının şoklara nasıl tepki göstereceğidir (Clarida vd., 1999, s. 1665). Optimum para politikası teorisi para politikasını bir bilim olarak görür. $\mathrm{Bu}$ ise şunu vurgulamaktadır: İktisatçılar, "iyi” bir para politikası uygulamak için neyi bilmeleri gerektiğini bilmelidirler. Teori, politika yapıcıların hanehalkının faydasını maksimize etmeyi amaçlayan iyi niyetli merkez bankacılar olduğu varsayımına dayanmaktadır. $\mathrm{Bu}$ dinamik optimizasyon problemi ise veri kaynaklar, kurumlar ve bilgi kısıtı altında çözülmektedir. Merkez bankasının amaç fonksiyonu hedef değişkenlerin davranışını, politika yapıcılar tarafından karar süreçlerinde kullanılan refah ölçümüne dönüştürmektedir. Merkez bankasının optimum hedef fonksiyonunun önceden belirlenmiş enflasyon oranı ve potansiyel çıtıyı içerdiği varsayılmaktadır. Amaç fonksiyonu kayıp fonksiyonu olarak belirlendiği için merkez bankası gelecekte beklenen refah kayıplarını minimize etmeye çalışır. Bu refah kayıpları, çıktının ve enflasyonun ilgili hedef değerlerinden sapması sonucu ortaya çıkmaktadır. Enflasyondaki bir düşüşü geçici bir çıktı kaybının izlediğini göz önünde bulundurduğumuzda para politikası kararlarının marjinal faydası ve marjinal maliyetinin dengelenmesi bakımından bu politika optimum olmaktadır (Walsh, 2001, s. 15).

Merkez bankasının optimizasyona dayalı davranışında asıl amacı kayıp fonksiyonunu minimize etmektedir. Bu fonksiyona göre enflasyonun hedeften, çıktının ise denge düzeyinden sapmasının bir maliyeti bulunmaktadır. Merkez bankası, bu sapmalardan kaynaklanan faydasızlığa katlanmaktadır. Bu tür bir faydasızlık, pozitif ve negatif sapmalara ilişkin olarak simetriktir ve sapmanın büyüklüğüne oranla kayıp artmaktadır. Bu nedenle kayıp fonksiyonunu çıktının ve enflasyonun karesel fonksiyonu olarak yazmak daha uygun olmaktadır. Bu kayıp fonksiyonunu sözü edilen iki amaca eşit ağırlık veren bir merkez bankası için aşağıdaki şekilde ifade edilmektedir:

$\min . L_{t}=\left(\frac{1}{2}\right) E_{t} \sum_{i=0}^{\infty} \beta_{i}\left(\pi_{t+i}^{2}+\lambda \tilde{y}_{t+i}^{2}\right)$

İhtiyata dayalı para politikası yürüten merkez bankas1 ekonominin cari durumu ve özel sektör beklentilerini veri alarak her bir dönemde optimum şekilde davranmaktadır. Kamuoyunun merkez bankasının her dönemde optimizasyon yaptığını bildiğini kabul edersek, merkez bankasının gelecek hakkında verdiği 
taahhütleri inandırıcı olmayacaktır. Geçmişte merkez bankası her ne söz vermiș olursa olsun, politikasının gereği olan şeyi yapacaktır, yani optimum olan neyse onu yapacaktır.

Taahhüte dayalı rejimde ise merkez bankası gelecekte ne olacağı hakkında güvenilir sözler verebilir. Merkez bankası gelecekte izleyeceği kesin politikalar hakkında söz vererek gelecekteki enflasyon hakkında kamunun beklentilerini etkileyebilir. Walsh (2010, s. 358) politikalar üzerinde ileriye dönük beklentilerin rol oynadığı bir ortamda, ihtiyata dayalı politikanın istikrar sağlayıcı bir politika olduğunu belirtmektedir.

Merkez bankasının temel amacı çıktı ve enflasyonda istikrarı sağlamaktır. Bu amaçla nominal faiz oranını belirlerken enflasyonun hedeften sapmalarını, çıktı açığındaki değişimi dikkate almaktadır. Literatürde Taylor (1993) kuralı olarak bilinen temel para politikası aşağıdaki gibidir (Gali, 2002, s. 24):

$i_{t}=r_{t}^{n}+\phi_{\pi} \pi_{t}+\phi_{y} \tilde{y}_{t}$

Taylor kuralını para politikası tepki fonksiyonu olarak aşağıdaki şekilde yazabiliriz:

$i_{t}=\rho_{r} i_{t-1}+\left(1-\rho_{r}\right)\left(\phi_{\pi} \pi_{t}+\phi_{y} \tilde{y}_{t}\right)+v_{t}$

(3.3)'de $v_{t}$ sıfır ortalamaya sahip stokastik dişsal bileşendir. $\phi_{\pi}$ ve $\phi_{y}$ 'nin negatif olmayan bileşenler olduğunu ve parasal otorite tarafından seçildiğini varsayalım. Bu iki katsayı sırasıyla merkez bankasının enflasyona ve çıktıya duyarlılığını ölçmektedir. $\rho$ sabit katsayısı faiz oranı düzeltme derecesidir (degree of interest rate smoothing) ve faiz oranı kuralını $\left(i_{t}\right)$ sıfir enflasyon denge durumu ile uyumlu hale getirmektedir.

Yeni Keynesyen modelin optimum para politikası uygulamasının iki temel sonucu bulunmaktadır. Bunlardan birincisi, Blanchard ve Gali (2007a)'nin "ilahi tesadüf" (divine coincidence) olarak adlandırdıkları durumdur. Buna göre istenilen koşullar altında (bunlar Yeni Keynesyen modelde sağlanan koşullardır) enflasyonda istikrarı sağlamak çıktının da en iyi düzeyinden uzaklığında istikrarı sağlayacaktır. Buna refah ile ile ilgili çıktı açığı denilmektedir. Bu para politikası açısından önemli bir çıkarımdır. Buna göre merkez bankaları sadece enflasyona odaklanmalıdır. Eğer enflasyonda istikrarı sağlayabilirlerse otomatik olarak ekonomik faaliyetlerde de optimum düzeyi yaratabilirler. Başka bir ifadeyle, enflasyon yerine üretimi önemseyen bir politika önceliğine sahip bir merkez bankası bile enflasyona odaklanmalıdır. $\mathrm{Bu}$ nedenle enflasyon hedeflemesi para politikasının yürütülmesinde öne çıkmaktadır.

Modelin optimum para politikası ile ilgili ikinci önemli sonucu birinci sonucu ile ilişkilidir. Enflasyonda istikrarı başarmak için Taylor kuralına ihtiyaç vardır. Bu kural ile ifade edilen faiz oranının enflasyona tepki olarak ayarlanmasıdır. Temel koşul faiz oranının vereceği tepkinin enflasyondan daha fazla olması gerektiğidir. Kural, arz şoklarının varlığında bile enflasyonu optimum değerinde tutacak şekilde sağlamlığa sahip olmalıdır (Blanchard, 2006, s. 3).

\section{Faiz Oranı Kuralı Altında Denge Dinamikleri}

Dişa açık ekonomi için elde ettiğimiz üç temel denklem olan (2.2), (2.3) ve (3.3)'ü biraraya getirdiğimizde denge koşulunu ifade eden denklem sistemini elde ederiz. Ve bunu fark denklemleri şeklinde aşağıdaki gibi gösterebiliriz (Gali, 2008b, s. 165):

$$
\left[\begin{array}{c}
\tilde{y}_{t} \\
\pi_{H, t}
\end{array}\right]=A_{\alpha}\left[\begin{array}{c}
E_{t}\left\{\tilde{y}_{t+1}\right\} \\
E_{t}\left\{\pi_{t+1}\right\}
\end{array}\right]+B_{\alpha}\left(r_{t}^{n}-v_{t}\right)
$$

(3.4)'de $r_{t}^{n} \equiv r_{t}^{n}-\rho \quad$ dir ve

$$
A_{\alpha} \equiv \Omega_{\alpha}\left[\begin{array}{cc}
\sigma_{\alpha} & 1-\beta \phi_{\pi} \\
\sigma_{\alpha} \kappa_{\alpha} & \kappa_{\alpha}+\beta\left(\sigma_{\varepsilon}+\phi_{y}\right)
\end{array}\right] \quad B_{\alpha} \equiv \Omega_{\alpha}\left[\begin{array}{c}
1 \\
\kappa_{\alpha}
\end{array}\right] \quad \Omega_{\alpha} \equiv \frac{1}{\sigma_{\alpha}+\phi_{y}+\kappa_{\alpha} \phi_{\pi}} \quad \text { olmaktadır }^{3}
$$

3 Negatif olmayan katsayılar $\left(\phi_{\pi}, \phi_{y}\right)$ varsayımı altında yerelde tek durağan denge koşulu aşağıda gibi gösterilebilir (Bullard ve Mitra, 2002):

$$
\kappa_{\alpha}\left(\phi_{\pi}-1\right)+(1-\beta) \phi_{y}>0
$$




\section{Modelin Para Politikası Açısından Sonuçları}

Yeni Keynesyen model dört önemli alanda para politikası ile ilgili güçlü sonuçlara sahiptir. Bunlar (King, 2000 ve Zimmermann, 2003) :

i) Fiyat düzeyi veya enflasyon hedeflemesinin önemi: Düşük düzeyde enflasyon hedefleyen para politikası ekonomiyi potansiyel hasılasına yakın bir düzeyde tutacaktır. Eğer ekonomide dışsal bir enflasyon şoku yoksa, istikrarlı fiyat düzeyi aynı zamanda çıktıyı da potansiyel düzeyinde tutacaktır. Daha genel bir şekilde ifade edersek yeni model şunu göstermektedir: Zaman ile değișen enflasyon hedefleri verimlilik, toplam talep, para talebi gibi şokları içeren ekonomik bozukluklara tepki vermemelidir.

Merkez bankasının uygulayacağı enflasyon hedeflemesi esnek olmalıdır. Bir başka ifadeyle, merkez bankası çıktı ve enflasyonu dengede tutmalıdır. $\mathrm{Bu}$ nedenle merkez bankası kısa dönem Phillips eğrisindeki değiş-tokuş’u göz önünde bulundurarak fiyat istikrarına çıktıdaki istikrardan daha fazla önem vermelidir.

ii) Enflasyon hedeflemesi altında faiz oranının davranış/hareketi: Yeni model Irving Fisher tarafından geliştirilen, modern makroekonomi’nin temel taşlarından birisi olan faiz oranı belirlenmesinin iki prensibini birleştirmektedir. Reel faiz oranı zamanlar arası anahtar nispi fiyattır. Reel ekonomide büyüme beklentisi var ise artar, yavaşlama beklentisi var ise düşer. Nominal faiz oranı, beklenen enflasyon ve reel faiz oranının toplamıdır. Bu nedenle, potansiyel düzeyine yakın bir hasılayı devam ettirmeye dönük enflasyon hedeflemesi izleyen bir merkez bankası, ekonominin beklenen büyüme oranı arttığında nominal faiz oranını artırmalı, beklenen büyüme oranı gerilediğinde ise nominal faiz oranını düşürmelidir.

iii) Para politikasının sinırları: Modelde para politikasının iki sınırı bulunmaktadır. Birincisi, parasal otorite çıktıyı potansiyel düzeyinde kalıcı bir biçimde tutamaz. İkincisi, ekonomide rasyonel beklentilere dayalı tek bir denge var ise para politikası kuralları k1sıtlanmalıdır. Özellikle, çoğu ekonomide ortaya çıktı$\breve{g}_{1}$ gibi, merkez bankasının faiz oranını politika aracı olarak kullandığı ve enflasyon oranı belirlenen hedefin üzerine çıktığında faiz oranını artırdığı varsayılır. Eğer ekonomide istikrarlı ve tek bir denge olursa bu politika agresif bir şekilde uygulanır. Fakat, merkez bankası hem şimdi hem de gelecekteki enflasyonu dikkate alan bir politika izliyorsa enflasyon şoklarına karşı agresif bir şekilde tepki vermemesi önemlidir.

Merkez bankası kayıp fonksiyonunda yer alan çıktı istikrarı hedefinin ağırlığı ve sayısal enflasyon hedefi bakımından şeffaflığını devam ettirmek zorundadır. Bu sayede merkez bankası aşırı şekilde ihtiyata dayalı politika yürütmemiş olacaktır.

iv) Para politikasının etkileri: Yeni Keynesyen modelde para politikası çıtıyı potansiyel düzeyinden geçici olarak ayıracak etki yaratabilir. Buna rağmen, bazı önceki modellerin aksine, bu farklılıklar genellikle seri olarak bağlantısızdır. Merkez bankası nominal gelirde kalıcı bir artış yaratırsa, bu çıktıda da bir artış yaratacaktır. Fakat bu artış birkaç dönem sonra fiyat ayarlamaları tamamen yayıldığında ortadan kalkacaktır.

\section{Model Tahmini}

\section{Ampirik Literatür}

Yeni Keynesyen DSGD modelini kullanan ilk önemli çalışma Smets ve Wouters (2003) tarafından gerçekleştirilmiştir. Bu çalışma sonraki çalışmalar için de her zaman yol gösterici olma niteliğine sahiptir. Yazarlar Euro bölgesi için yapışkan ücret ve fiyatlara dayalı DSGD modeli geliştirmişlerdir. Model alışkanlık oluşturma, sermaye birikiminde uyarlanma maliyeti, kapasite kullanım özellikleri gibi parametreler içermektedir. Çalışmada Bayesci teknikler kullanılarak para politikası şokları, verimlilik şokları, maliyet itişli şoklar ve diğer yapısal şokların (tercihler, emek arzı vb.) ampirik analizi yapılmakta ve bu şokların Euro bölgesinde iş çevrim dalgalanmalarına olan etkileri incelenmektedir. Çalışmanın sonuçlarına göre Euro bölgesinde fiyat ve ücret yapışkanlığı yüksektir. Kısa dönemde para politikası şoku etkili olmaktadır.

Tovar (2006) Şili, Kolombiya ve Meksika'daki devalüasyonların çıktı üzerindeki etkilerini analiz etmek için DSGD modeli kullanmıştır. Çalışmada modelin tahmini için maksimum olabilirlik yöntemi kullanılmıştır. Buna rağmen tahmin stokastik tekillik problemi yaratmaktadır. Bu problem çözmek için ilave şoklar yaratılmıştır. İkinci aşama tahmin ölçüm hataları dahil edilerek gerçekleştirilmiştir. Çalışmanın sonuçlarına göre devalüasyonun çıktı üzerinde genişlemeci 
yönde etkileri bulunmaktadır. Ödemeler bilançosuna bağlı aktarım mekanizması Meksika'da Şili’ye ve Kolombiya’ya göre daha zayıftır.

Medina ve Soto (2006) Şili ekonomisi için DSGE modeli geliştirmişlerdir. Modelde yatırımlardaki uyarlanma maliyeti ve tüketim davranışındaki alışkanlık kalıcığına bağlı olarak ücret ve fiyatlar yapışkandır ve ithalat fiyatlarına kur geçişkenliği tam değildir. Çalışmada modelin tahmini için Bayesci yöntemler kullanılmakta ve ihraç mallarına, yurtdışı çıktıya ve parasal şoka yönelik şoklar analiz edilmektedir. Sonuçlara göre ticari mal fiyatlarına yönelik bir şok tüketim ve yatırım artışları ile yurt içi hasılada genişlemeye neden olmaktadır. Ayrıca reel kurdaki değerlenme enflasyonu düşürmekte ve istihdamı azaltmaktadır. Para politikası şokları enflasyonda düşüşe neden olurken tüketim, yatırım ve yurtiçi hasıla üzerinde pozitif etki yaratmaktadır.

Da Silveria (2006) Brezilya ekonomisi için dişa açık küçük ekonomi DSGD modeli geliştirmiştir. Modelin önemli özelliklerinden birisi ticaret hadlerini enflasyonu besleyen maliyet itişli bir değişken olarak Yeni Keynesyen Phllips eğrisi denklemine sokmasıdır. Bu sayede kapalı ekonomileri belirten çıktı açığı ve marijnal maliyet arasındaki ilişki ortadan kalkmaktadır. Çalışmada Bayesci yöntemler kullanılmıştır. Sonuçlara göre yüksek ticaret hadleri dış rekabetçiliği artırarak dünya talebini ülke malına yöneltmektedir. Yüksek çıktı işgücü piyasasını hareketlendirmekte, reel ücreti ve marijinal maliyeti yukarı çekmektedir. Yüksek ticaret hadleri yurtiçi mallar bakımından reel ücreti ve marjinal maliyeti artırmaktadır.

Liu (2006) Yeni Zelanda için dişa açık küçük ekonomi DSGE modeli geliştirmiştir. Model özellikle temel politika simülasyonlarına bir araç sağlamak için parasal aktarım mekanizmasına odaklanmaktadır. Model Bayesci yöntemler ile tahmin edilmektedir. Çalışmanın sonucuna göre dönemlerarası tüketimin ikame edilebilirliği çok azdır. Bunda ekonomide yabancı malların yakın ikamelerinin üretilmemesinin etkisi vardır. Hareketsiz işgücü, işgücü arzı kararlarının düşük esnekliği tarafından desteklenmektedir. Fiyat sözleşmelerinin süresinin ithal perakencileri için dört çeyrek yurtiçi üreticiler için beş çeyrek olduğu tahmin edilmektedir.
Buncic ve Melecky (2008) Avustralya ekonomisi için Bayesci teknikler yardımıyla dışa açık Yeni Keynesyen model kullanmışlardır. Çalışmada makroekonomik dalgalanmalar üzerinde dış şokların mı yoksa iç şokların mı etkili olduğu araştırılmaktadır. Çalışmanın sonuçlarına göre yurtdışı ve yurtiçi talep şokları ile yurtiçi arz şokları ekonomideki iş çevrimleri üzerinde etkili olmaktadır. Reel döviz kurunun çıktı üzerindeki etkisi gecikme ile ortaya çıkmaktadır. Enflasyon yurtiçi arz şoklarına karşı oldukça hassastır. Para politikasının enflasyon üzerindeki etkisi ise düşük olmaktadır.

Breuss ve Rabitsch (2008) Bayesci yöntemi kullanarak Avusturya ve Euro bölgesi için iki ülkeli DSGD modeli geliştirmişlerdir. Model reel ve nominal katılıkları dayalı olarak oluşturulmuştur. Burada amaç hem Avusturya ekonomisindeki iş çevrimlerinin kaynaklarını açılayabilmek hem de diğer AB ülkeleri ile arasındaki çeşitli yapısal şokların aktarımını açıklayabilmektir. Bu yapısal şoklar teknoloji, tercihler, maliyet itişli şoklar ve politika şoklarıdır. Model ayrıca parasal rejim değişkliğinin de etkilerini araştırmaktadır. Sonuçlara göre Avusturya ekonomisi talep şoklarına daha güçlü tepki göstermekte, Euro bölgesinin geri kalanında ise arz şokları daha güçlü etkiye sahip olmaktadır. Avrupa parasal birliğine katılım öncesi ve sonrasına göre Euro bölgesi şoklarının Avusturya ekonomisine etkisi önemli bir şekilde artış göstermiştir.

Kucsera vd. (2009) Macaristan ekonomisi için orta ölçekli DSGD modeli kullanarak optimum para politikasını incelemişlerdir. Model iki sektörün yer aldığı, üretim için ithal ara malı kullanan, nominal ve reel katılıkların bulunduğu bir çerçeve içerisinde geliştirilmiştir. Çalışmanın modelleme açısından önemli sonucu; küçük modellerde iyi şekilde analiz edilen para politikası uygulamasının orta ölçekli modellerde de iyi bir şekilde belirlenebildiğidir. Bir başka ifadeyle, nominal katılıklar ile alakalı bozuklukları ortadan kaldırmayı amaçlayan refah maksimizasyoncu politika enflasyon hedeflemesi kuralı tarafından yaklaştırilabilir.

Khan ve Haider (2009) Bayesci yönyemler yardımıyla Pakistan ekonomisini için küçük dışa açık DSGD modeli tahmin etmişlerdir. Model hanehalkının tüketiminde alışkanlık oluşturmanın ve fiyatlarda 
katılı̆̆ın yer aldığı Yeni Keynesyen çerçeveye dayalı olarak oluşturulmaktadır. Çalışmanın amacı yurtiçi firmaların fiyatlama davranışları aracılı̆̆ıyla işleyen parsal aktarım mekanizmasının yardımıyla Pakistan ekonomisinin yapısı hakkında gerçekçi bir davranış sağlamaktır. Model yardımıyla temel makro değişkenlerin etki tepkilerini analiz etmektir. Bunlar yurtçi enflasyon, ithalat, enflasyonu, çıtı, tüketim, faiz oranı, döviz kuru ve ticaret hadlerinin farklı yapısal-dışsal şoklara tepkileridir. Çalışmanın sonuçlarına göre yüksek enflasyon tüketimi olumsuz etkilemekte, $\mathrm{Pa}$ kistan merkez bankası yüksek enflasyona faiz oranlarını 100-200 baz puan artırak tepki vermekte, yurtiçi ve ithal enflasyonu durumlarında döviz kuru değer kazanmakta, sıkı para politikası enflasyon üzerinde etkili olurken kurun artmasına neden olmaktadır. Buna rağmen yurtiçi enflasyona kur geçişkenliği çok düşüktür.

Buriel vd. (2010) Bayesci yöntemler kullanarak İspanya ekonomisi için DSGD modeli geliştirmişlerdir. Çalışmanın amacı politika analizi ve karşıolgusal (counterfactual) alıştırmalar için İspanya ekonomisinin temel özelliklerini tanımlamaktır. Model Yeni Keynesyen nominal ve reel katılıklar çerçevesinde olşuturulmakta ve modele küçük dişa açık ekonomi, dışsal parasal otoroite (Avrupa Merkez Bankası) ve nüfus büyümesi gibi İspanya ekonomisinde dalgalanmaları etkileyen faktörler eklenmektedir.

Sen ve Sun (2011) Çin ekonomisi için Smets-Wouters modeline parasal büyüme kuralını ekleyerek Taylor kuralının yer aldığı yeni bir DSGD modeli geliştirmişlerdir. Modelin tahmininde Bayesci yöntem kullanılmıştır. Çalışmanın amacı Çin ekonomisinde iş çevrimleri üzerinde parasal ve parasal olmayan değişkenlerin rolünü ve para politikası aktarım sürecini incelemektir. Modelde piyasa başarısızlıkları ve nominal yapışkanlıklar gibi Yeni Keynesyen özellikler yer almaktadır. Modelin parasal büyüme kuralı ve Taylor kuralı bakımından sonuçları, parasal aktarım meknizmasının ve parasal ve parasal olmayan şokların iş çevrimlerine yönelik çeşitli katkılarını vurgulamaktadır.

Rabana ve Quint (2011) Euro bölgesi için geliştirdikleri DSGD modelinde parasal ve makro-sakıngan (macro-prudential) politikaların birlikte kullanımını incelemişlerdir. Model nominal, reel ve finansal anlaşmazlıkları içerdiği için hem parasal hem de makro sakıngan politikalar modelde önemli bir role sahiptir. Çalışmanın sonucuna göre makro sakıngan kuralın modele dahil edilmesi refahı artırmada ve makroekonomik oynaklığı azaltmada yardıcı olabilir. Buna rağmen makro sakıngan düzenlemelerin etkileri çok ılımlıdır ve merkez bankasının para politikası kuralının yaratacağından daha küçük bir sayısal etkiye sahiptir. Makro sakıngan düzenleyici aşırı risklerin oluşmasından kaçınmak için kredi/GSYİH oynaklığını minimum yapmak amacına sahip olduğunda, makro sakıngan politikalar sayısal olarak daha önemli olmaktadır.

Peersman ve Stevens (2013) Bayesci yöntemler ile geliştirdikleri DSGD modelinde petrol talebi ve arzı tarafından tetiklenen şokları incelemişlerdir. Yazarlar Amerika ve petrol üreten ülkelerin yapısal bir modelini geliştirmekte ve tahmin etmektedirler. Çalışmanın sonuçlarına göre petrol fiyatlarındaki değişmelerin farklı kaynakları farklı makroekonomik etkilere neden olmaktadır. Reel petrol fiyatındaki dalgalanmalar Amerikan ekonomisindeki macoekonomik gelişmeler ile ilgili olarak çoğunlukla dışsaldır.

Çebi (2011) Bayesci teknikler kullanarak Türkiye için Yeni Keynesyen dışa açık DSGE modeli tahmin etmektedir. Çalışmanın amacı para ve maliye politikası arasındaki etkileşimleri ve bunların ekonominin istikrarında rolünü incelemektir. Çalışmada Lubik ve Schorfheide’ın (2000) geliştirdikleri küçük ölçekli model kullanılmaktadır. Kullanılan modelin genel özellikleri Calvo tipinde nominal fiyat katılıkları, döviz kurunun tam geçişkenliği, tam uluslarası varlık piyasaları, genel kabul görmüş kurala dayalı fiyat belirleyiciler ve bozucu vergileme yer almaktadır. Çalışmanın sonuçlarına göre parsal otorite enflasyona çıktı açığına oranla daha güçlü tepki göstermektedir. Faiz oranı düzeltme derecesi yüksektir. Maliye politikası borç istikrarına katkı sağlamaktadır.

Alp ve Elekdağ (2011) Bayesci tahmin yöntemine dayalı olarak geliştirdikleri DSGD modeli yardımıyla küresel finans krizi süresince Türkiyede para politikasının rolünü incelemektedirler. Modele nominal ve reel katılıkları ve dışa açık ekonomide finansal hızlandırıcı mekanizması eklenmektedir. Çalışmanın sonucuna göre para politikasında enflasyon hedeflemesi rejimine geçiş ve dalgalı kur rejimi gibi reformlar yapılmış olmasaydı krizin etkisinin daha fazla olacağı belirtilmektedir. 
Yüksel (2013) Bayesci yöntem yardımıyla dışa açık küçük ekonomi için DSGD modeli geliștirmișitr. Çalışmanın amacı çıktıdaki dalgalanmaları açıklamada yatırım şoklarının rolünü araştırmaktır. Model yapışkan fiyat ve ücretler, değişken sermaye kullanımı, yatırım uyarlanma maliyetleri ve alışkanlık kalıcılığı gibi nominal ve reel katılıklar içermektedir. Çalışmanın sonucuna göre kalıcı teknoloji şoku Türkiye ekonomisindeki iş çevrimlerinin belirleyici gücü olmaktadır ve yatırım şokunun etkisi daha kısa sürelidir.

\section{Tahmin Yöntemi}

Ampirik literatürde DSGD modellerinin parametrelerini belirlemede kullanılan çok sayıda yöntem bulunmaktadır. $\mathrm{Bu}$ yöntemlerin başlıcaları Kydland ve Prescott (1982) ile Gali ve Monacelli (2005) tarafindan kullanılan saf kalibrasyon (pure calibration) yöntemi, Christiano ve Eichenbaum (1992) tarafindan kullanılan genelleştirilmiş momentler yöntemi (generalized methods of moments), Kim (2000) ve Ireland (2004) tarafindan kullanılan tam bilgiye dayalı maksimum olabilirlik tahmini (maximum likelihood estimation) yöntemidir. Bunların dışında DSGD modelinin veriye uygun olup olmadığını araştıran kısıtlı bilgiye dayalı yöntemlerde bulunmaktadır. Canova (2002) ve Christiano vd. (2005) VAR ve DSGD modellerinin etki tepki fonksiyonunu tahmin etmek için minimum uzaklığa dayalı kriter (minimum distance based criterion) geliştirmişlerdir. Bu çalışmada Bayesci tahmin yöntemi kullanılmaktadır. Bayesci tahmin yöntemi diğer tahmin yöntemlerine göre bazı avantajlara sahiptir. Bunlardan birincisi, tahmin sürecinde ilave bilgi sağlayan önsel dağılımlardan yararlanılmasıdır. Griffoli (2013) tahmin sürecine önsel bilginin dahil edilmesinin modelin parametrelerini belirlemede kolaylık sağladığını belirtmektedirler. İkincisi, genelleştirilmiş momentler yöntemi tek bir eşitliğe dayalı olarak kullanılırken Bayesci yaklaşım sisteme dayalı tahmine imkan sağlamaktadır. Bu bizim genel denge yaklaşımının avantajlarından faydalanmamızı sağlar. Üçüncüsü, Bayesci yaklaşımın küçük örneklemlerde diğer iki tahmin yöntemi olan genelleştirilmiş momentler ve maksimum olabilirlik yönteminden daha iyi tahmin performansı sağlamasidir (Rabanal ve Ramirez, 2005, s.1160).

DSGD modellerinde Bayesci yöntemlerin ilk kullanıldığı çalışmalar Landon-Lane (1998), Dejong vd. (2000), Schorfheide (2000) ve Otrok’a (2001) aittir. Lubik ve Schorfheide (2005) tarafından yaklaşım genelleştirilmiştir.

\section{Bayesci Tahmin Yaklaşımı}

Bayesci yaklaşım seçilmiş model parametrelerinin tahmininin ve kalibrasyonunun birlikte kullanıldı $\breve{g}_{1}$ bir yöntemdir. Bu yaklaşımın temel avantajı, ekonomideki mevcut koşullara modelin adapte edilmesinin sağlanmasıdır. Bayesci tahmin yöntemi model parametrelerini tahmin etme, modelin öngörülerini oluşturma ve model kıyaslamalarını yönetme imkanı vermektedir.

Ampirik modellerde belirsizliğin üç olası kaynağı bulunmaktadır. Bunlar; modelin kendisi ile modelin ve verinin parametrik hale getirilme koşuludur. Belirsizlik konusu Klasik yaklaşım ve Bayesci yaklaşım arasındaki farkı sağladığı için çok önemlidir. Klasik yaklaşımda bir olayın meydana gelme olasılığı onun sıklı̆̆ıyla ilgili belirsizliğin ölçümüdür. Bayesci yaklaşımda bir olayın meydana gelme olasılığı olaya yönelik araştırmacının nesnel inanışının derecesi olmaktadır. Bu da iki bileşen tarafından belirlenmektedir. Bunlar nesnel (sübjektif) inanış olarak adlandırılan önsel (prior) ve bu olayın sıklığı (olasılık fonksiyonu) olmaktadır.

Bayesci teoremde ortaya çıkan elemanları veri $(y)$, yapisal parametreler $(\alpha)$, önsel bilgi $(p(\alpha))$ ve örneklem bilgisi $(f(y / \alpha) \equiv L(\alpha / y)) \quad$ olarak belirtebiliriz. Buna göre Bayes teoremi aşağıdaki eşitlik yardımıyla bize parametrelerin sonsal dağılımını vermektedir (Schorfiede, 2011, s.8):

$$
p(\alpha / y)=\frac{f(y / \alpha) p(\alpha)}{f(y)}
$$

(4.1)'de $p(\alpha / y)$ parametrelerin sonsal dağılımı olmaktadır. Bu sonsal dağılım ile ifade edilen mevcut gözlemlerimize bağlı olarak $\alpha$ 'nın koşullu olasılığıdır. $f(y / \alpha)$ olabilirlik fonksiyonu, $p(\alpha)$ önsel dağılım, $f(y)=\int f(y / \alpha) p(\alpha) d \alpha$ ise marjinal olabilirlik ya da koşulsuz örneklem yoğunluğudur. (4.1)'in ifade ettiği sonuç aslında olasılık kuralının basit uygulamasından hareketle parametre değerleri hakkındaki inanışlarımızı nasıl güncellememiz gerektiğini söylemektedir ${ }^{4}$. Bir başka ifadeyle, önsel bilgimiz $p(\alpha)^{\prime} y 1$ olabilirlikle şekillendirilen örneklem bilgisi $p(y / \alpha)$ ile birleştirerek yeni bir inanışlar kümesi yani $p(\alpha / y)$ 'yı elde ederiz. Sonsal dağılım; önsel, veri ve model

\footnotetext{
4 Teoremin kullandığı basit olasılık kuralı şu şekildedir: $P(A, B)=P(A / B) P(B)=P(B / A) P(A)$
} 
parametre koşullarına göre olasılıksal (olasılığa dayalı) açıklamalar yapmak için kullanılabilir. Sonsal dağılım aynı zamanda aşağıda ifade edilen sonsal çekirdek değerine de bağlı olmaktadır:

$$
p(\alpha / y) \infty L(y / \alpha) p(\alpha)
$$

(4.2)' de önsel $p(\alpha)$, tahminci için $\alpha$ parametresi hakkındaki herhangi bir bilgiyi içermektedir. Böylece (4.2) no'lu ifade, tahmincinin model parametreleri ile ilgili olarak önsel inanışlarını güncellemek için veri gözlemlerini kullanan güncelleme kuralı olarak yorumlanabilir.

Bayesci teoride olabilirlik fonksiyonu önemli bir yere sahiptir. Çünkü modelin tahmini, modelin logaritmik-doğrusal şeklinin çözümü tarafından yaratılan olabilirlik fonksiyonuna dayalı olmaktadır. Olabilirlik fonksiyonunu elde etmek için ise modelin indirgenmiş formu olan durum-uzay (state-space) araçlarına ve filtreleme teorisine ihtiyaç vardır.

DSGD modelinin logaritmik-doğrusal forma dönüştürülmüş denklemlere dayalı çözümünü elde ettikten sonra durum-uzay gösterimini kullanarak değişkenlerin hareket kuralını (law of motion) yazabiliriz. Durum-uzay gösterimi iki eşitlikten oluşmaktadır (Fernandez-Villaverde, 2010, s. 15):

Durum / Geçiş eşitliği: $S_{t}=f\left(S_{t-1}, \varepsilon_{t}, \alpha\right)$

Gözlem / Ölçüm eşitliği: $Y_{t}=g\left(S_{t}, \mu_{t}, \alpha\right)$

(4.3)'de $S_{t}$ herhangi bir mevcut anda modelin durumunu tanımlayan durum vektörü, $\varepsilon_{t}$ stokastik şoklara yönelik değişimleri gösteren vektör, $\alpha$ ise teknoloji, tercihler ve bilgi süreçlerini tanımlayan yapısal parametre vektörüdür. (4.4)'de yer alan $Y_{t}$ ve $\mu_{t}$ ise sirasıyla gözlemleri ve gözlemlere yönelik şok kümesini belirtmektedir.

DSGD modelleri rasyonel beklentilere dayalı doğrusal denklem sistemi formuna sahiptir ve bu aşağıdaki şekilde yazılmaktadır (Dejong vd., 2000, s. 209):

$S_{t}=A_{1}(\alpha) S_{t-1}+A_{2}(\alpha) \varepsilon_{t}$

$\varepsilon_{t}=A_{3}(\alpha) \varepsilon_{t-1}+A_{4} \mu_{t}$

(4.5)'de eşitlik modelin içsel değişkenlerinin değiş̧imini tanımlayan ve (4.3)'deki ifadenin benzeri olan bir geçiş eşitliğidir. (4.6)'daki $\varepsilon_{t}$ eşitliği şokların bü- tününü temsil etmektedir. $A_{i}$ ise modelin parametrelerine bağlı olan katsayı matrisidir. (4.5) ve (4.6)'nın gözlemlenen değerler ile olan ilişkisi ise (4.4)'deki ifadenin benzeri olan aşağıdaki gözlem eşitliği ile sağlanmaktadır:

$Y_{t}=D(\alpha) S_{t}$

(4.7)'de D deterministik matris olmaktadır. (4.5) ve (4.6) modelin durum-uzay formunu temsil ederler. Olabilirlik fonksiyonu değer tahmini için Kalman Filtresi kullanılmaktadır. Kalman Filtresi, durum uzayı modeli ile gösterilen dinamik sistemde, modelin önceki bilgileriyle birlikte giriş ve çıkış bilgilerinden sistemin durumlarını tahmin etmek için kullanilir.

Filtreleme teorisi yardımıyla olabilirlik fonksiyonunun değer tahminini elde ettikten sonra maksimizasyon yada tanımlama yardımıyla onu bulmamız gerekmektedir. Bunun için de sonsal dağılımı bulmamız gerekir. Uygulamada sonsal dağılım basit bir forma sahip değildir. Örneğin model parametresi $\alpha$ 'nın nokta tahmini için bir aday sonsal dağılım ortalaması aşağıdaki şekilde olmaktadır (Herbst, 2010, s.4):

$$
E(\alpha)=\int \alpha p(\alpha / y) d \alpha
$$

(4.8)'deki integrali elde etmek için sayısal yöntemlere başvurulmaktadır. Markov-Chain-Monte-Carlo (MCMC) yöntemi bunlardan biridir. Bu yöntemde amaç; ergodik ${ }^{5}$ dağılıma, yani sonsal $p(\alpha / y)$ 'e sahip bir Markov zinciri $\left\{\alpha_{j}\right\}$ yaratmaktır. Matematikte, Markov zinciri, Markov özelliğine sahip bir stokastik süreçtir. Markov özelliğine sahip olmak, mevcut durum verildiğinde, gelecek durumların geçmiş durumlardan bağımsız olması anlamına gelir. Bir başka ifadeyle, mevcut durumun açılaması, sürecin gelecekteki evrimini etkileyecebilecek tüm bilgiyi kapsamaktadır. Gelecek durumlara belirli bir şekilde değil, olasılıksal bir süreçle ulaşılacaktır.

Her bir anda sistem belirli bir olasılık dağılımına bağlı olarak kendi durumunundan başka bir duruma geçebilir yada aynı durumda kalabilir. Durumda olan değişiklikler geçiş, çeşitli durum değişmeleriyle ilişkili olasılıklar da geçiş olasılıkları olarak adlandırilmaktadir.

5 Geçmiş istatistiklerden yararlanarak geleceğe dair bilgi üretme yaklaşımına "ergodik" denilmektedir. 
Markov zinciri yaratmak için çeşitli algoritmalar kullanılmaktadır. Metropolis-Hastings (MH) algoritması bunlardan biridir (Fernandez-Villaverde, 2010, s. 22).

Bu bölümde açıklanan Bayesci yöntem adımlarını basit bir şekilde özetleyebiliriz:

- Öncelikle önsel inanışlar formüle edilmektedir. Bir başka ifadeyle $p(\alpha)$ seçilmektedir.

- İkinci adımda veri için model formüle edilmektedir. $p(y / \alpha)$ 'nın koşullu olasılığı bulunmaktadir.

- Son olarak veri gözlemlenmekte, üzerinde $\alpha$ koşulunun olabilirliği incelenmekte ve buna bağlı olarak $\alpha$ hakkındaki inanışlar güncellenmektedir.
Bu çalışmada tüm bu işlem adımları için MATLAB programı üzerinde çalışan ve Dinamik Stokastik Genel Denge Modellerinin tahmini için geliştirilen DYNARE araç kutusu (toolbox) kullanılmaktadır.

\section{Ampirik Analiz}

Bu bölümde bir önceki bölümde teorik olarak açıklanan tahmin yöntemine dayalı olarak model tahmine hazır hale getirilmektedir.

\section{Modelin Logaritmik-Doğrusal Gösterimi}

Tahmin için kullanılacak dişa açık küçük ekonomi modelinde içsel değişkenler için onbir, dişsal süreçler için üç eşitlik yer almaktadır. Tablo 1'de bu değişkenler açıklanmaktadır.

İçsel değişkenler veriye dayalı olarak elde edilen değişkenlerdir. Modelde içsel değişkenler sırasıyla yur-

\begin{tabular}{ll} 
Tablo 1. Modelde Yer Alan Değişkenler & \\
\hline İçsel değişkenler & $\left\{y_{t} ; y_{t}^{F} ; \pi_{t} ; \pi_{F, t} ; r_{t} ; r_{t}^{*} ; q_{t}\right\}$ \\
\hline İçsel durum değişkenleri & $\left\{\psi_{t} ; c_{t} ; m c_{t} ; \pi_{H, t} ; s_{t}\right\}$ \\
\hline İçsel yenilikler & $\left\{a_{t} ; v_{t}^{\pi, H} ; v_{t}^{\pi, F} ; v_{t}^{r} ; v_{t}^{r^{*}} ; v_{t}^{q} ; v_{t}^{s}\right\}$ \\
\hline Dişsal şoklar & $\left\{v_{t}^{a} ; v_{t}^{y^{*}} ; v_{t}^{r^{*}}\right\}$ \\
\hline
\end{tabular}

tiçi çıktı, yurtdışı çıktı, tüketici fiyat endeksi, yurtdışı enflasyon oranı, yurtiçi faiz oranı, yurtdışı faiz oranı ve reel döviz kuru olmaktadır.

İçsel durum değişkenleri ise modele verinin dahil edilmesi sonrası elde edilen değişkenlerdir. Bunlar da sırasıyla tek fiyat kanunu açı̆̆ı, tüketim, marjinal maliyet, yurtiçinde üretilen mallar için enflasyon oranı ve dış ticaret hadleridir. Burada dış ticaret hadleri için de veri kullanılmaktadır.

İçsel yenilikler modele yönelik şokları ifade etmektedir. Bu şoklar veriye dayalı değişkenlere verilen şokar sonrası ilgili dönem için gerçek değişimleri ortaya çıkarmaktadır. Bu şoklar sırasıyla teknoloji düzeyi, yurtiçi fiyat şoku, yurtdışı fiyat şoku, yurtiçi faiz şoku, yurtdışı faiz şoku, reel döviz kuru şoku ve ticaret hadleri şoku olmaktadır.
Dışsal şoklar ise ekonominin kendi iç dinamiklerinden kaynaklanmayan şokları ifade etmektedir. Bu şoklar sırasıyla teknoloji şoku, yurtdışı çıktı şoku ve yurtdışı faiz şoku olmaktadır.

Çalışmanın üçüncü bölümünde dışa açık ekonomi modeli kısmında elde edilen eşitlikler Tablo 2'de logaritmik-doğrusal olarak toplu bir şekilde yeniden gösterilmektedir. Ekonominin genel dengesi bu eşitlikler yardımıyla oluşturulmaktadır.

Burada mal piyası denge koşulu, yurtiçinde üretilen malların enflasyonu ve ithal malları enflasyonu ile ilgili eşitlikler için Haider ve Khan (2008) tarafından önerilen eşitlikler kullanılmıştır. Bu modelin genel yapısında ve işleyişsinde bir değişim ortaya çıkarmamaktadır. Burada amaç değişkenler arası ilişkileri basit ve daha anlaşılır şekilde ortaya koymaktır. 
Tablo 2. Modelin Standart Gösterimi

\begin{tabular}{|c|c|c|}
\hline 1. & Mal piyasası denge koşulu & $\tilde{y}_{t}=(1-\alpha)\left\{c_{t}+\alpha \eta s_{t}\right\}+\alpha\left\{\eta\left(s_{t}+\psi_{t}\right)+y_{t}^{*}\right\}+\alpha \eta \psi_{t}$ \\
\hline 2. & $\begin{array}{l}\text { Yurtiçinde üretilen } \\
\text { malların enflasyonu }\end{array}$ & $\pi_{H, t}=\beta\left(1-\theta_{H}\right) E\left\{\pi_{H, t+1}\right\}+\theta_{H} \pi_{H, t-1}+\lambda_{H} m c_{t}+v_{t}^{\pi, H}$ \\
\hline 3. & Ithal mallart enflasyonu & $\pi_{F, t}=\beta\left(1-\theta_{H}\right) E_{t}\left\{\pi_{F, t+1}\right\}+\theta_{F} \pi_{F, t-1}+\lambda_{F} m c_{t}+v_{t}^{\pi, F}$ \\
\hline 4. & Toplam enflasyon & $\pi_{t}=\left[(1-\alpha) \pi_{H, t}+\alpha \pi_{F, t}\right]$ \\
\hline 5. & Firmanın marjinal maliyeti & $m c_{t}=\varphi y_{t}+\alpha s_{t}+\frac{\sigma}{1-h}\left(c_{t}-h c_{t-1}\right)-(1+\varphi) a_{t}$ \\
\hline 6. & Tüketimin Euler denklemi & $\left(c_{t}-h c_{t-1}\right)=E_{t}\left(c_{t+1}-h c_{t}\right)-\left(\frac{1-h}{\sigma}\right)\left(r^{t}-E_{t} \pi_{t+1}\right)$ \\
\hline 7. & Açık faiz paritesi & $E_{t} \Delta q_{t+1}=-\left(r-\pi_{t+1}\right)-\left(r^{*}-\pi_{t+1}^{*}\right)+v_{t}^{q}$ \\
\hline 8. & Ticaret hadleri & $s_{t}=s_{t-1}+\pi_{F, t}-\pi_{H, t}+v_{t}^{s}$ \\
\hline 9. & Tek fiyat açı̆̆ı kanunu & $\Psi_{t}=-q_{t}-(1-\alpha) s_{t}$ \\
\hline 10. & $\begin{array}{l}\text { Uluslararası risk paylaşım } \\
\text { koşulu }\end{array}$ & $\left(c_{t}-h c_{t-1}\right)=y_{t}^{*}-h y_{t-1}^{*}-\left(\frac{1-h}{\sigma}\right) q_{t}$ \\
\hline 11. & $\begin{array}{l}\text { Para politikast } \\
\text { tepki fonksiyonu }\end{array}$ & $r_{t}=\rho_{r} r_{t-1}+\left(1-\rho_{r}\right)\left(\phi_{1} \pi_{t}+\phi_{2} \Delta y_{t}\right)+v_{t}^{r}$ \\
\hline 12. & Dışsal süreçler & $\begin{array}{l}a_{t}=\rho_{a} a_{t-1}+v_{t}^{a} \\
y_{t}^{*}=\lambda y_{t-1}^{*}+v_{t}^{y^{*}} \\
r_{t}^{*}-E_{t} \pi_{t+1}^{*}=\rho_{r}\left(r_{t}^{*}-E_{t} \pi_{t}^{*}\right)+v_{t}^{r^{*}}\end{array}$ \\
\hline
\end{tabular}

\section{Veri}

Modelin tahmininde ekonomide ortaya çıkan sekiz şok inceleneceği için sekiz değişkene ait gözlem degerleri kullanılmaktadır. Şok sayısı kadar gözlem değeri olmasının sebebi ise stokastik tekillik ve tanımlama problemlerinden kaçınmaktır ${ }^{6}$.

6 Stokastik tekillik (stochastic singularity) problemi şokların sayısı gözlem sayısından az olduğunda ortaya çıkmaktadır. Benzer şekilde gözlemlenen değişken sayısının da şokların sayısından az olması istenen bir durum değildir. Her iki durum da şokların zayıf belirlenmesine yol açmaktadır.
Analizde 2002:Q1 ve 2012:Q4 arasındaki çeyrek dönemlik veri seti kullanılmaktadır. Verilerin elde edilmesinde TCMB Elektronik Veri Dağıtım Sistemi (EVDS), Uluslararası Para Fonu'nun (IMF) veri tabanı IFS (International Financial Statistics) ve Avrupa Birliğinin veri tabanı Eurostat kullanılmıştır. Veri tanımları detaylı olarak aşağıda Tablo 3'de açıklanmaktadır.

Mevsimsel etkilerden arındırılan seriler daha sonra HP Filter $(\lambda=1600)$ yöntemi ile trendlerinden ayrıștırılmıştır. 
Tablo 3. Veri Tanımları

\begin{tabular}{|c|c|c|c|}
\hline 1. & $y_{t}$ & Yurtiçi çıktı & $\begin{array}{l}\text { Türkiye'nin kişi başı GSYİH gözlemleri } \\
\text { kullanılmıştır. }\end{array}$ \\
\hline 2. & $y_{t}^{f}$ & Yurtdış1 çıktı & $\begin{array}{l}\text { Avrupa Birliği’nde kişi başına çıktıdaki yıllık artış } \\
\text { oranı kullanılmıştır. }\end{array}$ \\
\hline 3. & $\pi_{t}$ & Yurtiçi enflasyon & TÜFE'deki yıllık artış oranı kullanılmıştır. \\
\hline 4. & $\pi_{F, t}$ & Ithalat enflasyonu & $\begin{array}{l}\text { Türkiye'nin ithalat birim endeksinin yıllık artış oranı } \\
\text { kullanılmıştır. }\end{array}$ \\
\hline 5. & $r_{t}$ & Yurtiçi faiz oranı & $\begin{array}{l}\text { Bankalararası para piyasası gecelik faiz oranının } \\
\text { ağırlıklı ortalaması kullanılmıştır. }\end{array}$ \\
\hline 6. & $r_{t}^{*}$ & $\begin{array}{l}\text { Yurtdışı reel faiz } \\
\text { oranı }\end{array}$ & $\begin{array}{l}\text { Amerikan ekonomisine ait kısa dönem piyasa faiz } \\
\text { oranı ve enflasyon oranı kullanılarak hesaplanan } \\
\text { değerler kullanılmıştır. }\end{array}$ \\
\hline 7. & $q_{t}$ & Reel döviz kuru & $\begin{array}{l}\text { Türkiye için TÜFE bazlı reel efektif döviz kuru } \\
\text { değeri kullanılmıştır. }\end{array}$ \\
\hline 8. & $s_{t}$ & Ticaret hadleri & $\begin{array}{l}\text { İthalat birim endeksinin ihracat birim endeksine oranı } \\
\text { hesaplanarak kullanılmıştır. }\end{array}$ \\
\hline
\end{tabular}

\section{Kalibrasyon}

Parametrelerin kalibrasyonu, tahminin başlangıcında seçilmiş parametrelere sabit değerler atanması işlemidir. Bu parametrelerin bir kısmı durum değişkenle- rinin durağan durum değerleri ile doğrudan ilişkili olurken ve önemli durağan durum oranlarını açıkça belirtmek için seçilirken, bir kısmı da literatürde daha önceki yapılmış çalışmalardan elde edilebilir.

Tablo 4. Parametrelerin Kalibrasyonu

\begin{tabular}{lll}
\hline Parametre & Tanımı & Değer \\
\hline$\alpha$ & Dışa açılık ölçüsü & 0,27 \\
\hline$h$ & Tüketim alışkanlığı derecesi & 0,70 \\
\hline$\beta$ & İskonto faktörü & 0,9928 \\
\hline$\sigma$ & Tüketimin dönemler arası ikamesinin esnekliğinin tersi & 3 \\
\hline$\eta$ & Yurtiçinde üretilen mallar arasındaki dönemler arası ikame esnekliği & 1 \\
\hline$\theta_{H}$ & Yurtiçi fiyat yapış̧kanlığı & 0,50 \\
\hline$\theta_{F}$ & Yurtdışı fiyat yapış̧kanlığı & 0,50 \\
\hline$\phi_{1}$ & Enflasyon açı̆̆ına tepki katsayısı & 1,50 \\
\hline$\phi_{2}$ & Çıktı açığına tepki katsayısı & 0,25 \\
\hline$\phi$ & Çıktıdaki artışın marjinal maliyet üzerindeki etkisi & 1 \\
\hline$\rho_{r}$ & Faiz oranı düzeltme katsayısı & 0,70 \\
\hline
\end{tabular}


Dışa açıklık derecesi ithalatın GSYİH'ye oranının ilgili dönem için ortalamasıdır. Bu oran 0,27 olarak hesaplanmıştır. Literatürde tüketim alışkanlığının dönemler arasında çok büyük bir şekilde değişiklik göstermediği belirtilmektedir. Bu nedenle ilgili parametre değeri 0.70 olarak belirlenmiştir. İskonto faktörü 0.9928 olarak belirlenmiştir. Bu değer yıllık risksiz reel faiz oranının \%3 civarında olarak kabul edilmesidir. Bu değer Alp ve Elekdağ (2011) ve Yüksel (2013) tarafından da Türkiye için kullanılmaktadır. Dışa açıklık derecesi ve iskonto oranı parametreleri ilgili dönem için sabit kullanılmştır. Bir başka ifadeyle parametrelerin tahminine gerek bulunmamaktadır. Tüketimin dönemler arası ikamesinin ters esnekliği için parametre değeri 3 seçilmektedir. Bu tüketimdeki ikame esnekliğinin 0,33 (1/3) olduğu anlamına gelmektedir. Çebi (2011) bu oranı Türkiye için 3 olarak kullanmıştır. Literatürde de ilgili parametre değeri için farklı kullanımlar söz konusudur. Lubik ve Schorfheide (2007) Kanada için Ortiz vd. (2009) Türkiye için bu parametre değerini 2 olarak seçmektedirler. Fragetta ve Kirsanova (2010) Birleşik Krallık için 3, İsveç için 2,5 ve Amerika için 5 değerini seçmektedirler. Yurtiçinde üretilen mallar arasındaki dönemler arası ikame esnekliği için parametre değeri olarak 1 tercih edilmiştir. Bu değerin bire eşit olması parametresinin ekonominin dışa açıklı̆̆ını gösteren doğal bir endeks yerine geçmesini sağlamaktadır.

Yurtiçi ve yurtdışı fiyat yapışkanlıkları için tercih edilen Calvo parametresi 0.50 'dir. Bu değer fiyat sözleşmelerinin ortalama süresinin 6 ay olduğunu ifade etmektedir. Standart hatanın 0.25 olarak belirlenmesi 3-9 ay arası bir değişime izin vermektedir. Enflasyonun 2002 başındaki yüksek değeri ve enflasyon ataletinin varlığı Türkiyedeki fiyat değişimlerinin gelişmiş ülkelere oranla daha sık olmasına etki edebilir.

Para politikası kuralının parametrelerinin seçiminde merkez bankasının fiyat istikrarı öncelikli bir politika yürütmesi durumundan hareketle enflasyon üzerindeki katsayı ağırlığı daha yüksek bir değer olarak belirlenmektedir. Lubik ve Schorfheide (2007) Kanada için yaptıkları çalışmalarında enflasyon için tepki katsayısını ve standart hatayı sırasıyla 1.5 ve 0.5 olarak belirlemektedir. Bu daha sonra bir çok çalışmada temel kalibrasyon değeri olarak kullanılmıştır. Alp ve Elekdağ (2011) ise Türkiye için sırasıyla 1.4 ve 0.25 değerlerini kullanmışlardır. Çıktı açı̆ı̆ına tepki katsay1s1 olarak Ortiz vd. (2009) 0.20 standart hataya sahip 0.25 değerini kullanmışlardır. Çebi (2011) ise Türkiye için 0.4 değerini 0.20 standart hata ile kullanmıştır. Lubik ve Schorfheide (2007) ve Ortiz vd. (2009) Kanada ve Türkiye için faiz oranı düzeltme katsayısı olarak 0.2 standart hataya sahip 0.5 değerini kullanmaktadır. Çebi (2011) bu değeri 0.5 olarak almaktadır. Yüksel (2013) ve Alp ve Elekdağ (2011) ise 0.7 değerini kullanmışlardır. Bu çalışmada da enflasyon açığına tepki katsayısı 1,50 olarak belirlenmektedir. Çıktı açığına tepki katsayısı ve faiz oranı düzeltme katsayısı için ise sırasıyla 0,25 ve 0,70 değerleri tercih edilmektedir.

\section{Önsel Dağılım}

Modelin parametreleri ve şoklarla ilgili seçilen önsel dağılımlar ile ilgili değerler ve seçilen dağılımlar Tablo 8'de yer almaktadır. Önsel dağılımların seçiminde literatür takip edilmiştir. Pozitif parametrelerin gamma dağılıma, 0-1 arası değer alan parametrelerin beta dağılımına, şokların ters gamma dağılımına, geriye kalanların ise normal dağılıma sahip olduğu varsayilmaktadır. Önsel'lerin ortalama ve standart hata seçimleri için de literatürdeki önceki çalışmalardan yararlanılmıştır.

DSGD modellerinin Bayesci analizinde dışsal şok sürecinin hareket yasasını belirleyen parametler hakkındaki inanışları formüle etmek mümkün olmamaktadır. Bu nedenle şokların büyüklüğünü belirlenmesi olabildiğince serbest bir şekilde veri'ye bırakılmaktadır (Adofson vd.,2007). Bu durumda standart hata 2-4 olarak belirlenebilmektedir.

\section{Tahmin Sonuçları}

\section{Önsel ve Sonsal Dağılımlar}

Tablo 5'de model parametrelerinin tahmin sonuçları gösterilmektedir. Parametrelerin sonsal dağılımları Metropolis-Hastings algoritması kullanılarak \%90 güven aralığı ile tahmin edilmiştir. Sonuçlar 100000 çekim ve 2 bağımsız zincir opsiyonu kullanılarak Markov Chain Monte Carlo yöntemine dayalı olarak belirlenmiştir. Brooks ve Gelman (1998) yakınlaşma kriterinin sağlanmış olması ve zincir başına \%25.3'lük kabul oranı sonuçların genel kabulü için yeterli olmaktadır. 
Tablo 5. Önsel ve Sonsal Dağılımlar

\begin{tabular}{|c|c|c|c|c|c|c|}
\hline & & Onse & limlar & & Sonsal dağılı & \\
\hline Parametre & Dağılım & Ortalama & $\begin{array}{l}\text { Std. } \\
\text { Sapma }\end{array}$ & Ortalama & Std. Sapma & $\begin{array}{l}\text { Güven } \\
\text { aralığı }\end{array}$ \\
\hline$h$ & Beta & 0.70 & 0.20 & 0.5629 & 0.4864 & 0.6179 \\
\hline$\sigma$ & Normal & 3.00 & 0.40 & 1.687 & 1.665 & 1.705 \\
\hline$\eta$ & Gamma & 1.00 & 0.40 & 1.0502 & 0.6733 & 1.3997 \\
\hline$\phi$ & Gamma & 1.00 & 0.40 & 1.3224 & 1.1024 & 1.5732 \\
\hline$\theta_{H}$ & Beta & 0.50 & 0.25 & 0.6038 & 0.5712 & 0.6379 \\
\hline$\theta_{F}$ & Beta & 0.50 & 0.25 & 0.6730 & 0.6474 & 0.6995 \\
\hline$\phi_{1}$ & Gamma & 1.50 & 0.20 & 1.6283 & 1.4535 & 1.8183 \\
\hline$\phi_{2}$ & Gamma & 0.25 & 0.10 & 0.3049 & 0.2208 & 0.4035 \\
\hline$\rho_{r}$ & Beta & 0.70 & 0.20 & 0.5077 & 0.4230 & 0.5675 \\
\hline$\rho_{r}^{*}$ & Beta & 0.50 & 0.20 & 0.6063 & 0.2850 & 0.9132 \\
\hline$\rho_{a}$ & Beta & 0.80 & 0.20 & 0.8000 & 0.8000 & 0.8000 \\
\hline$\lambda_{1}$ & Beta & 0.50 & 0.20 & 0.3457 & 0.2044 & 0.4919 \\
\hline$v_{a}$ & $\begin{array}{l}\text { Inverse } \\
\text { Gamma }\end{array}$ & 2.00 & 0.50 & 2.9793 & 2.4795 & 3.3797 \\
\hline$v_{y}^{*}$ & $\begin{array}{l}\text { Inverse } \\
\text { Gamma }\end{array}$ & 1.00 & 0.20 & 1.0295 & 0.8963 & 1.1717 \\
\hline$v_{r}^{*}$ & $\begin{array}{l}\text { Inverse } \\
\text { Gamma }\end{array}$ & 0.50 & 0.20 & 1.0492 & 0.8937 & 1.1954 \\
\hline$v_{\pi, h}$ & $\begin{array}{l}\text { Inverse } \\
\text { Gamma }\end{array}$ & 2.00 & 0.25 & 1.6286 & 1.3208 & 1.9353 \\
\hline$v_{\pi, f}$ & $\begin{array}{l}\text { Inverse } \\
\text { Gamma }\end{array}$ & 1.00 & 0.10 & 2.1561 & 2.1260 & 2.1798 \\
\hline$v_{r}$ & $\begin{array}{l}\text { Inverse } \\
\text { Gamma }\end{array}$ & 1.00 & 0.10 & 1.2952 & 1.1510 & 1.4098 \\
\hline$v_{q}$ & $\begin{array}{l}\text { Inverse } \\
\text { Gamma }\end{array}$ & 2.00 & 0.10 & 2.8334 & 2.8220 & 2.8435 \\
\hline$v_{s}$ & $\begin{array}{l}\text { Inverse } \\
\text { Gamma }\end{array}$ & 2.00 & 0.10 & 2.7520 & 2.6818 & 2.8410 \\
\hline
\end{tabular}

Tahmin sonuçları ile ilgili ilave bilgi önsel ve sonsal dağılımlarının çekirdek tahminlerini veren Şekil 2'den elde edilebilir. Burada açık renkli çizgiler ilgili parametrelerin önsel dağılımını, koyu renkli çizgiler ise sonsal dağılımını vermektedir. Kesikli dikey çiz- giler ise tahmin sonucu elde edilen nokta tahminleri göstermektedir. Sonuçlar önsel ve sonsal ortalamaların çoğu durumda önemli ölçüde farklılaştığını göstermektedir. 

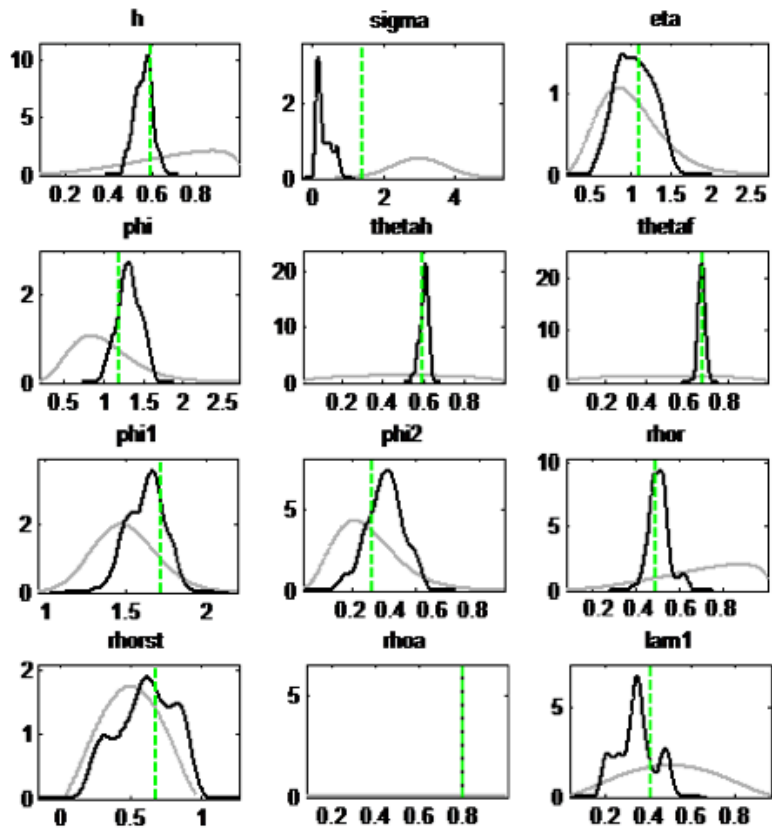

Şekil 2. Katsayı Parametrelerinin Dağılımları

Para politikası kuralı ile ilgili parametrelerin tahmin sonuçlarına göre parasal otorite enflasyona yönelik aktif bir politikayı $\left(\phi_{\pi}=1.63\right)$ tercih ederken, çıktı açığına aşırı tepki vermemektedir $\left(\phi_{\tilde{y}}=0.30\right)$. Faiz oranı düzeltme katsayısıda literatüre yakın bir değerle elde edilmektedir $\left(\rho_{r}=0.50\right)$.

Çebi (2011) 2002:Q1 - 2009:Q3 dönemi için enflasyona ve çıktı açığına tepki katsayılarını sırasıyla 1.75 ve 0.41 olarak bulmuştur. Alp ve Elekdağ (2011) 2002:Q1 - 2010:Q1 dönemi için enflasyon tepki katsayısını 1.54, çıktı açı̆̆ tepki katsayısını 0.02 olarak bulmuşlardır. Yüksel (2013) ise 2002:Q1 - 2012:Q2 dönemi için enflasyon tepki katsayısını 1.39, çıktı açığ tepki katsayısını 0.035 olarak bulmuştur.
Parametre tahmin sonuçları yurtdışı ve yurtiçi mallar için fiyatların yenilenme süresinin 6-7 ay göstermektedir. Bu sonuçlar düşen enflasyon ortamında fiyatların yeniden belirlenme sürelerinin arttığını göstermesi bakımından önemlidir.

\section{Şokların Analizi: Etki- Tepki Analizi}

Şekil 3'de faiz artışına çıtı'ı'ın ve enflasyonun tepkileri stokastik simülasyona (kalibrasyon değerli parametler ile) dayalı olarak gösterilmektedir. Buradaki etki-tepki fonksiyonları parametrelerin kalibrasyon değerlerine dayalı olarak elde edilmektedir. Buna göre faiz kararının çıktı üzerindeki etkisi üçüncü dönemde ortaya çıkmakta ve yaklaşık dört dönem boyunca devam etmektedir. Faiz artışının enflasyon y

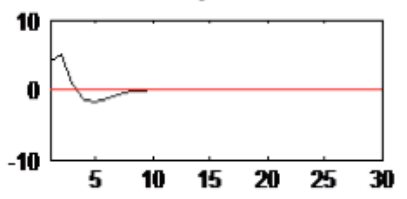

pi $t$

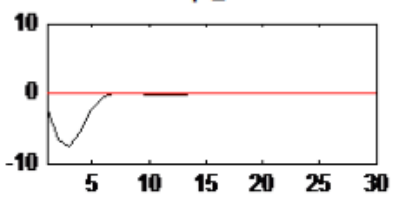

Şekil 3. Faiz Artışının Stokastik Simülasyon ile Etkisi 
üzerindeki etkisi ikinci veya üçüncü dönemde ortaya çıkmakta ve yedinci dönemde ortadan kalkmaktadır.

Şekil 4'de faiz artışına (nu_r) değişkenlerin tepkileri Bayesci etki-tepki fonksiyonlarına dayalı olarak gösterilmektedir. Grafiklerde gölgeli alanlar en yüksek sonsal yoğunluk aralıklarını, kalın çizgiler ise ortalama sonsal değerleri göstermektedir. Faiz artış şoku karşısında tüketim (c), çıkı (y), marjinal maliyet $(\mathrm{mc})$ ve enflasyon beklenildiği gibi negatif etki- lenmektedir. Hem yurtdışı fiyatlar (pi_f) hem tüketici fiyat endeksi (pi_t $t$ ) üzerinde faiz şokunun etkisi güçlü olmaktadır. Bununla birlikte faiz artışı reel kur (q) üzerinde de değerlenme yönünde etkili olmaktadır. Kurun düşmesi (yerli paranın değer kazanması) sonucu ithalat birim değer düşerken, ihracat birim değer endeksi yükselmektedir. Bu durum ise ticaret hadlerini (tot) artırmaktadır. Tek fiyat açı̆̆ı (psi_t) da negatif olmuştur.
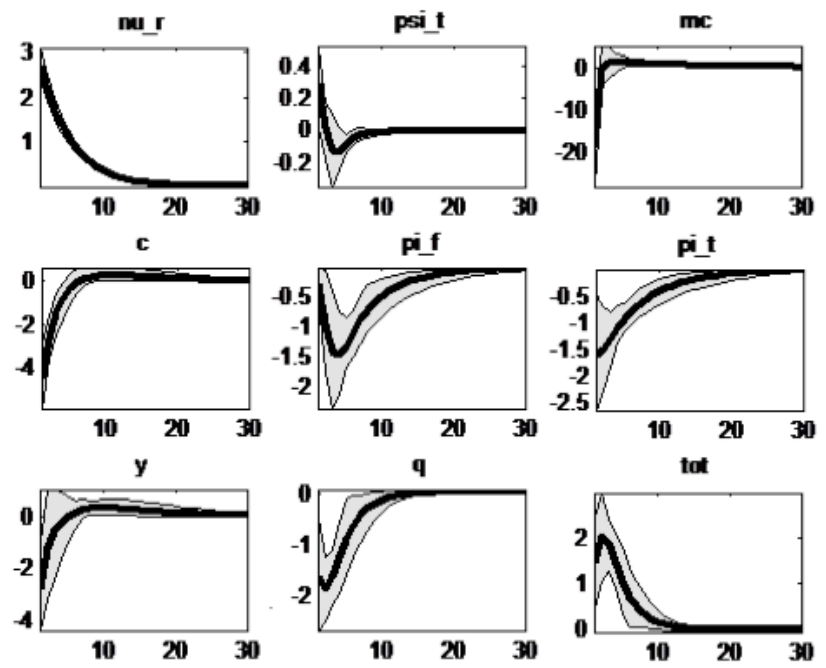

Şekil 4. Faiz artışına Bayesci Etki-Tepki Sonuçları

Şekil 5'de ise kur şoku (nu_q) karşısında değişkenlerin tepkileri gösterilmektedir. Kur şoku’nun tüketim ve çıktı üzerindeki etkisi pozitif olmaktadır. Aynı şekilde ithalat fiyatlarındaki artış üzerinden tüketici fiyatları üzerinde de artış yönünde etkili olmaktadır. Faiz oranları da kur şoku karşısında artış göstermektedir.

Şekil 6'da sırasıyla yurtdışı faiz artışına (nu_rst), yurtiçi mal fiyatları artışına (nu_pih), yurtdışı mal fiyatları artışına (nu_pif) ve verimlilik artışına (a) yurtiçi faiz oranı tepkileri gösterilmektedir. Yurtdışı faiz oranında yükselmeler karşısında yurtiçi faiz ora$\mathrm{n} ı$ da artarak tepki vermektedir. Yurtiçindeki üretilen mal fiyatları artışı, ithal malların fiyatlarındaki artışa oranla tüketici fiyatları üzerinde daha güçlü bir etkiye sahip olmaktadır. Fiyatlar genel düzeyindeki bu yükselişe faiz artışı tepkisi de güçlü olmaktadır. Çıktıda verimlilik artışı sonucu ortaya çıkan büyüme karşısında ise faiz oranı azalma yönünde tepki göstermektedir. 

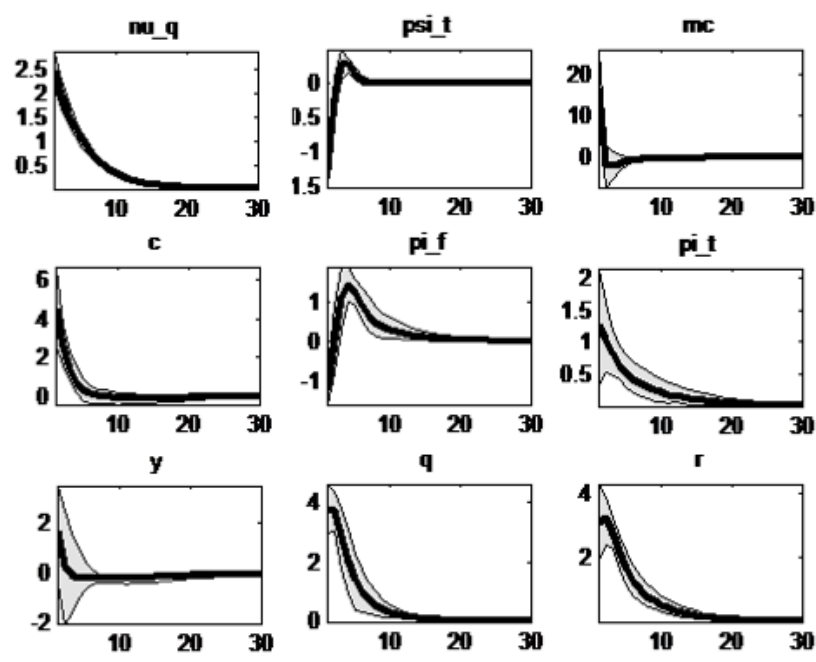

Şekil 5. Kur Şokuna Değişkenlerin Tepkisi
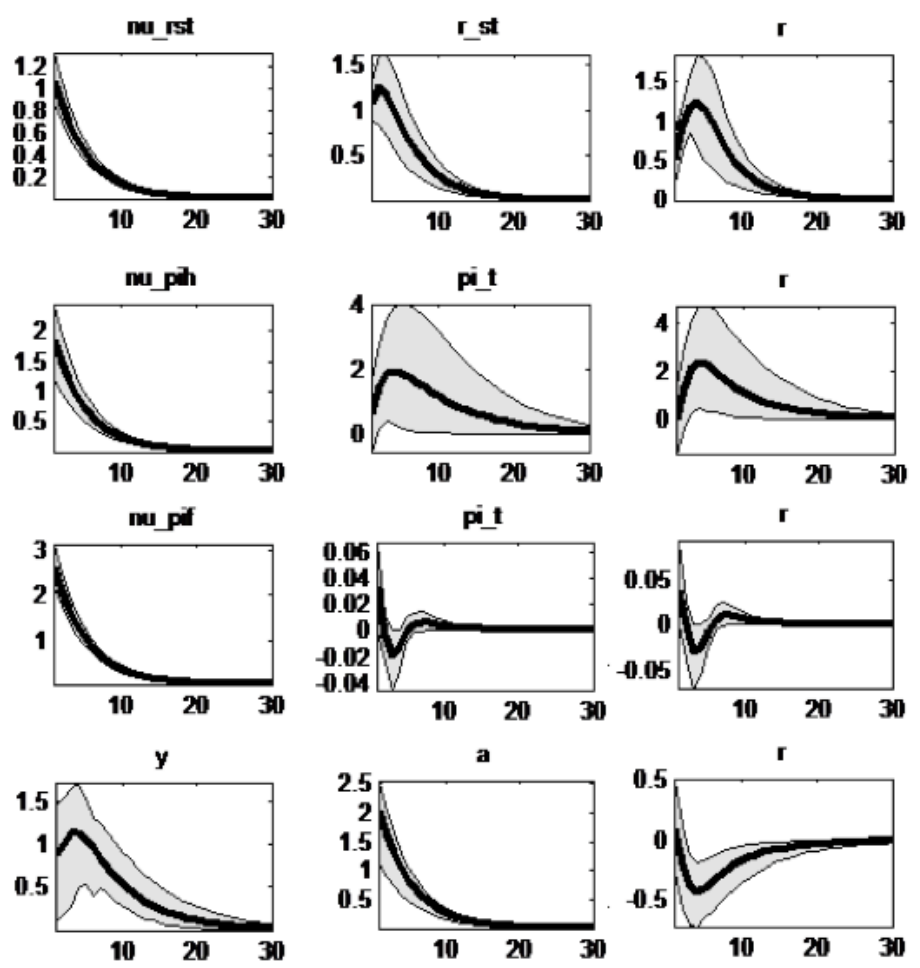

Şekil 6. Faiz Tepkileri 
Şekil 7'de her bir dönem için faiz oranı üzerinde değişkenlere ait şokların katkısının olduğu gösterilmektedir. Grafikte siyah çizgi belirli parametre setinde (burada sonsal dağılım ortalaması olmaktadır) faiz oranının düzeltilmiş (smoothed) değerinin durağan durumdan sapmasını göstermektedir. Renkli bar sütunlar ise faiz oranınının durağan durumdan sapmasına ilgili düzeltilmiş şokun katkısını göstermektedir. Başlangıç değerleri (initial values) ise durağan durumdan sapmanın düzeltilmişşoklar tarafindan açıklanmayan kısmını açıklamaktadır. Buna göre faiz oranının durağan durumdan sapmasına en çok katkıyı döviz kuru ile birlikte yurtdıșı faiz oranları ve fiyatlar sağlamaktadır. Kur düșüșleri bu dönemde gelişmiş ülkelerde düșen faiz oranları ve getiriler nedeniyle gelişmekte olan ülkelere yönelik sermaye girişlerinin etkisini göstermektedir. Sermaye girişleri sonucunda döviz kuru gerilemiş, TL değer kazanmış ve Merkez Bankasının faizleri düşürme yönünde eli kuvvetlenmiştir.

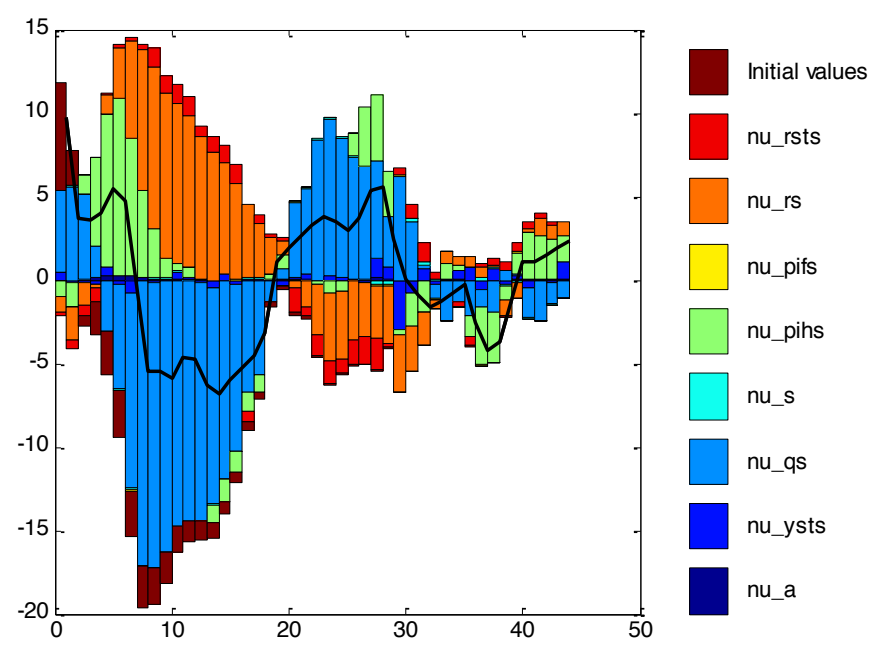

Şekil 7. Faiz Oranı Artışında Şokların Katkıları

\section{Sonuç}

Bu çalışmada Türkiye için Yeni Keynesyen makroekonomik çerçeve kullanılarak Dinamik Stokastik Genel Denge (DSGD) modeli tahmin edilmektedir. Çalışmanın amacı Optimum Para Politikası Teorisi kapsamında Türkiye'de uygulanan Enflasyon Hedeflemesi rejimi dönemini analiz etmektir.

Yeni Keynesyen DSGD modeli, sermayenin yer almadığı Reel İş Çevrimleri modelini başlangıç olarak almakta ve modele mal piyasasında monopolcü rekabet varsayımı ile kademeli nominal fiyat belirlemeyi ilave etmektedir. Yeni Keynesyen makroeokonomik çerçeve üç temel eşitliğe dayalı olarak oluşturulmaktadır. Bunlar; mal piyasası için IS denklemi, fiyat oluşum bloğu için Phillips eğrisi ve merkez bankasının faiz oranı tepki fonksiyonu olarak para politikası kuralıdır. Burada IS eğrisi ekonominin talep yönünü tem- sil ederken, Phillips eğrisi denklemi ise arz yönünü temsil etmektedir. Bu iki denklem aynı zamanda politik olmayan bloğu oluşturmaktadır. Para politikası kuralı olarak kullanılan faiz oranı tepki denklemi ise modelin politik bloğunu ifade etmektedir. Yeni Keynesyen modelde ekonomik dalgalanmaların merkezinde daha önce de ifade edildiği gibi nominal fiyat ve ücret katılıkları yer almaktadır. Mal piyasasında eksik rekabet söz konusudur ve firmalar "menü maliyetleri” ile karşı karşıya olmaları ve ürünlerine karşı artan talep karşısında fiyatlarını ayarlamada isteksiz olmaları nedeniyle ekonomi şoklara hızlı bir şekilde tepki verememektedir. Bu nedenle de para politikası kısa dönemde ekonomide istikrarı sağlama imkanına sahip olmaktadir.

Yeni Keynesyen modelde para politikası ise optimum para politikası teorisi çerçevesinde ele alınmaktadır. 
Burada merkez bankası bir amaç fonksiyonuna sahiptir. Amaç fonksiyonu hedef değişkenler olan enflasyon ve çıktının davranışını, politika yapıcılar tarafından karar süreçlerinde kullanılan refah ölçümüne dönüştürmektedir. Merkez bankasının optimum hedef fonksiyonunun önceden belirlenmiş enflasyon oranı ve potansiyel çıktıyı içerdiği varsayılmaktadır. Amaç fonksiyonu kayıp fonksiyonu olarak belirlendiği için merkez bankası gelecekte beklenen refah kayıplarını minimize etmeye çalışır. Bu refah kayıpları ise çıtının ve enflasyonun ilgili hedef değerlerinden sapması sonucu ortaya çıkmaktadır.

$\mathrm{Bu}$ çalışmada Yeni Keynesyen makroekonomik çerçeve kullanılarak dışa açık küçük DSGD modeli Türkiye için tahmin edilmektedir. Model nominal katılıklar, eksik rekabet ve hanehalkının tüketiminde alışkanlık oluşturma özelliklerine sahiptir. Bu sayede iktisadi ajanların optimum davranışlarının mikroekonomik temelleri sisteme dahil edilebilmektedir. Buradaki iktisadi ajanlar yurtiçinde yaşayan hanehalkları, yurtiçinde bulunan firmalar, parasal otorite ve yurtdışındaki sektör ekonomisi olmaktadır.

Çalışmanın bulgularına göre kur artışının fiyatlara geçişkenliği yüksektir. Buna göre ithalat fiyat endeksindeki artış tüketici fiyat endeksinde de artışa neden olmaktadır. Aynı şekilde kur artışı faiz oranlarında da bir yükselişe neden olmaktadır. Buradaki ilişkiyi kurdaki yükselişi bastırmak için faiz oranlarının artırılarak ekonomiye döviz girişinin sağlanması şeklinde açıklayabiliriz. Bununla birlikte, çalışmanın ele aldığ1 dönemde dünya ekonomisindeki küresel likidite bolluğu faizlerin düşmesinde etkili olmuştur. Gelişmiş ülkelerdeki düşük getirilerden kaçan fonlar nisbi olarak yüksek getirinin hala var olduğu Türkiye gibi gelişmekte olan ülkelere giriş yapmışlardır. Bu ortamda faiz oranlarının daha rahat bir şekilde düşürülmesi mümkün olmuştur.

Çalışmanın bir diğer sonucu fiyatlama davranışları ile ilgilidir. Türkiye ekonomisinde düssen enflasyon ile birlikte fiyatlama davranışlarının da değiştiği görülmektedir. 3-4 ay sıklığında değişen fiyatlar 6-7 aya kadar yükselmiştir. Bu fiyatlama süresi yurtdışı ve yurtiçi mallarda birbirine yakındır. Burada özellikle vurgulanması gereken uygulanan para politikasının etkili olduğu ve fiyatlama davranışlarında geçmişe değil gelecek döneme odaklı bir davranışın oluşmasıdır. Bu da enflasyon ataletinin ortadan kalktığını göstermektedir.
Yurtdışı faiz oranı olarak seçilen Amerikan ekonomisine ait faiz oranlarındaki düşüşler aynı şekilde yurtiçi faizlerin düşmesinde etkili olmaktadır. Yurtdışı faizlerin düşmesi sonucu küresel sermaye gelişmekte olan ülkelere yönelmektedir. Türkiye'de de faiz oranları düşüş trendinde olmasına rağmen nispi olarak yüksektir. Bu nedenle artan döviz girişi yerli paranın değerlenmesine etki etmektedir. Bunun sonucunda merkez bankası faiz oranlarını düşürerek bu değerlenmeyi dengelemeye çalışmaktadır.

Modelin para politikası tepki fonksiyonu olarak adlandırılan faiz oranı kuralında yer alan parametrelere ilişkin tahminlerine göre merkez bankası fiyat istikrarı amacı doğrultusunda enflasyondaki sapmalara daha güçlü tepki vermektedir. Bu daha önce Türkiye ekonomisi üzerine yapılan çalışmalarla aynı doğrultudadır. Çıktıya verilen tepkiler ise daha zayıf olmaktadır. Politika kararının (faiz artışının) enflasyon üzerindeki beklenen etkisi gecikmeli olarak ortaya çıktığı için enflasyon tahminleri önem kazanmaktadır. Başka bir ifadeyle etkin bir politika için tahmin performansının güçlü olması gerekmektedir.

Faiz artışının tüketim, fiyatlar, çıktı ve marjinal maliyet üzerindeki etkisi beklendiği gibi negatif olmaktadır. Faiz artışı aynı zamanda döviz girişini artırarak TL'nin değerlenmesine etki etmektedir. Bu da ihracatın azalması ithalatın artması sonucu dış ticaret dengesinin bozulmasina neden olmaktadır. Merkez bankasının sıklıkla faiz oranlarını daha da düşürmesi gerektiği konusunda aldığı eleştiriler biraz da bu etkinin varlı̆̆ını doğrulamaktadır.

Çalışmanın ele aldığ 1 dönemde enflasyon yüzde 68 seviyesinden yüzde 6 seviyesine gerilemiştir. Burada politika aracı olarak kullanılan faiz oranının özellikle beklentiler üzerinde de etkili olarak enflasyonun gerilemesinde etkili olduğu söylenebilir. Bununla beraber Türkiye ekonomisinde büyüme daha çok verimlilik artışına dayalı olarak gerçekleştiği için faiz oranı çıktı açığına fazla tepki vermemektedir. Çünkü bu bir anlamda talep artışına dayalı bir büyüme olmamaktadır. Fakat düşen faiz oranları aynı zamanda kredi maliyetlerini düşürerek tüketim üzerinde etkili olduğunda merkez bankası geçmiş dönemlerde faiz oranlarını artırarak tepki vermiştir. Merkez bankası ayrıca son dönemlerde finansal kesim üzerinde uyguladığı politikalarla da buradan gelecek talep artışını kontrol etmektedir. 
Sonuç olarak Türkiye ekonomisinde yaşanan iki kriz sonrası para politikası ve merkez bankacılığı önemli yapısal dönüşümler geçirmiş ve 2002 yılı ile birlikte bu yapı kapsamında yeni bir politika çerçevesi uygulamaya konulmuştur. Fiyat istikrarı amacını temel amacı olarak alan TCMB'nin ilgili dönem için bu amacından sapmadan etkin bir politika uyguladığ söylenebilir.

\section{Kaynakça}

Adjemian, S., Juillard, M., Mihoubi, F., Perendia, G. ve Villemot, S. (2009). Dynare Manual

Alp, H. ve Elekdağ, S. (2011). The Role of Monetary Policy in Turkey during the Global Financial Crisis. TCMB Working Paper No:11/10.

Allsop,C. ve Vines, D. (2000). The Assesment: Macroeconomic Policy. Oxford Review of Economic Policy, 16(4), 1-32.

An, S. ve Schorfheide, F. (2007). Bayesian Analysis of DSGE Models. Econometric Reviews, 26(2-4), 113172.

Adolfson, M.,Laseen,S.,Linde,J. ve Villani, M. (2007). Bayesian Estimation of an Open Economy DSGE Model with Incomplete Pass-Through. Journal of International Economics, Vol.72/Issue: 2, 458-511

Blanchard, O. (2006). Monetary Policy; Science and Art?. Panel discussion paper, Monetary Policy: A Journey from Theory to Practice.

Blanchard, O. ve Galí, J.(2007a). Real wage rigidities and the New Keynesian model. Journal of Money, Credit, and Banking, 39 (1), 35-65.

Breuss, F. ve Rabitsch, K. (2008). An Estimated TwoCountry DSGE Model of Austria and Euro Area. EI Working Paper, 78.

Brooks, S.P. ve Gelman, A. (1998). General Methods for Monitoring Convergence of Iterative Simulations. Journal of Computational and Graphical Statistics, Volume 7, Number 4, 434-455
Bullard, J. ve Mitra, K. (2002). Learning about Monetary Policy Rules. Journal of Monetary Economics, 49(6), 1005-1129.

Buncic, D. ve M. Melecky (2008). An Estimated New Keynesian Policy Model for Australia. The Economic Record, 84, 1-16.

Burriel, P., Villaverde, J.F. ve Ramirez, J.F. (2010). MEDEA: a DSGE model for the Spanish economy. SERIEs (2010) 1, 175-243

Calvo, G. (1983). Staggered Price Setting in a Utility Maximizing Framework. Journal of Monetary Economics, 12(3), 383-98.

Canova, F. (2002). Validating two monetary models via VARs. CEPR working paper, 3442 (13).

Christiano, L. ve M. Eichenbaum (1992). Current Real-Business Cycle Theories and Aggregate Labor Market Fluctuations. American Economic Review, $82,430-445$.

Christiano, L., M. Eichembaum ve C. Evans (2005). Nominal rigidities and the dynamic effects to a shock of monetary policy. Journal of Political Economy, 113, 1-45.

Clarida, R., Gali, J. ve Gertler, M. (1999). The Science of Monetary Policy: A New Keynesian Perspective. Journal of Economic Literature, 37, 1661-1707.

Clarida, R., Gali J. ve Gertler, M. (2000). Monetary Policy Rules and Macroeconomic Stability: Evidence and Some Theory. Quarterly Journal of Economics, 105(1), 147-80.

Çebi, C. (2011). The Interaction Between Monetary and Fiscal Policies in Turkey: An Estimated New Keynesian DSGE Model. TCMB Working Paper, No:11/04.

Da Silveira, M. A. C. (2006). A Small Open Economy as a Limit Case of a Two-Country New Keynesian DSGE Model: A Bayesian Estimation with Brazilian Data. Instituto de Pesquisa Econômica Aplicada Discussion Paper, 1252a. 
DeJong, D., B. Ingram, ve C. Whiteman (2000). A Bayesian Approach to Dynamic Macroeconomics. Journal of Econometrics, 98, 201-22.

Fernandez-Villaverde, J. (2010). The Econometrics of DSGE models. SERIEs (2010), 1, 3-49.

Fragetta, M. Ve Kirsanova, T. (2010). Strategic Monetary and Fiscal Policy Interactions: An Empirical Investigation. European Economic Review. Volume 54 / Issue: 7, 855-879.

Gali, J. (2002). New Perspectives on Monetary Policy, Inflation, and The Business Cycle. NBER Working Paper series. No: 8767. http://www.nber.org/papers/w8767.pdf

Gali, J. (2008a). The New Keynesian Approach to Monetary Policy Analysis: Lessons and New Directions. http://www.econ.upf.edu/docs/papers/downloads/1075.pdf.

Galí, J.(2008b). Monetary Policy, Inflation, and the Business Cycle: An Introduction to the New Keynesian Framework and its Monetary Policy Applications. Princeton: Princeton University Press.

Galí, J. ve Gertler M. (2007). Macroeconomic Modeling for Monetary Policy Evaluation. Journal of Economic Perspectives, 21(4), 25-45.

Gali, J. ve T. Monacelli (2005). Monetary Policy and Exchange Rate Volatility in a Small Open Economy. Review of Economic Studies, 72, 707-734.

Griffoli, T. M. (2013). DYNARE user manual: An introduction to the solution and estimation of DSGE models. www.dynare.org.

Haider, A. ve S.U. Khan (2008). A Small Open Economy DSGE Model for Pakistan. MPRA Paper, No. 12977

Herbst, E. (2010). Gradient and Hessian-based MCMC for DSGE Models. http://edherbst.net/derivativemcmc-dsge.pdf

Ireland, P.N. (2004). Money's Role in the Monetary Business Cycle. Journal of Money, Credit, and Banking, 36, 969-983.
Khan, S.U. ve Haider, A. (2008). A Small Open Economy DSGE Model for Pakistan. Munich Personal RePEc Archive, 12977.

King R. G. (2000). The New IS-LM Model: Language, Logic, and Limits. Federal Reserve Bank of Richmond Economic Quarterly, 86(3), 45-103.

Kim, J. ( 2000 ). Constructing and estimating a realistic optimizing model of monetary policy. Journal of Monetary Economics 45 ( 2 ): 329 - 359.

Kucsera, H., Jakab, Z.M., Szilagyi, K. ve Vilagi, B. (2009). Optimal monetary policy in an estimated DSGE Model for Hungary. Magyar Nemzeti Bank 2009 Conference. http://www.mnb.hu/Root/Dokumentumtar/ENMNB/Kutatas/mnben_konf_fomenu/mnben_conference2009/szilagyi_workshop2009.pdf (Erişim tarihi: 08.05.2010)

Kydland, F.E. ve Prescott, E.C. (1982). Time to Build and Aggregate Fluctations. Econometrica, 50, 13451370 .

Landon-Lane, J. 1998. Bayesian comparison of dynamic macroeconomic models. Ph.D. Dissertation, University of Minnesota.

Liu, P. (2006). A Small New Keynesian Model of the New Zealand economy. Reserve Bank of New Zealand. Discussion Paper Series, No. 03/06.

Lubik, T. ve Schorfheide, F. (2005). A Bayesian look at new open economy macroeconomics. (Ed: M. Gertler ve K. Rogoff). NBER Macroeconomics Annual, 313-336.

Medina, J. P. ve Soto, C. (2006). Model for Analysis and Simulations: A Small Open Economy DSGE for Chile. Conference Paper. Central Bank of Chile. http:// www.bcentral.cl/conferencias-seminarios/otrasconferencias/pdf/modelling2006/soto_medina. pdf (Erişim tarihi: 02.02.2013)

Ortiz, A., Ottonello, P., Sturzenegger, F. \& Talvi, E. (2009). Monetary and Fiscal Policies in a Sudden Stop: Is Tighter Brighter? In Dealing with an International Credit Crunch: Policy Responses to Sudden Stops in Latin America (E.Cavallo \& A. Izquierdo, Eds.). Inter-American Development Bank. 
Otrok, C. (2001). On Measuring the Welfare Cost of Business Cycles. Journal of Monetary Economics, 47, 61-92.

Peersman, G. ve Stevens, A. (2010). Oil Demand and Supply Shocks: An Analysis in an Estimated DSGE Model. Draft paper

Rabanal, P. ve Rubio-Ramirez, J.F. (2005). Comparing New Keynesian Models of the Business Cycle: A Bayesian Approach. Journal of Monetary Economics, 52(6), 1151-1166.

Rabanal, P. ve Quint, D. (2011). Monetary and Macroprudential Policy in an Estimated DSGE Model of the Euro Area. IMF 12th Jacques Polak Annual Research Conference.

Schorfheide, F. (2000). Loss Function Based Evaluation of DSGE Models. Journal of Applied Econometrics, 15, 645-670.

Schorfheide, F. (2011). Estimation and Evaluation of DSGE Models: Progress and Challenges. Federal Reserve Bank of Philadelphia Research Department. Working Paper, 11-7.

Sen, S. ve Sun, L. (2011). Monetary Policy Rules and Business Cycle in China: Bayesian DSGE Model Simulation. http://ssrn.com/abstract=1806347 (Erişim tarihi: 02.09.2012)

Smets, F. ve Wouters, R. (2003). Monetary Policy in an Estimated Stochastic Dynamic General Equilibrium Model of the Euro Area. Journal of the European Economic Association, 1, 1123-1175.
Strom, S.B. ve Poghosyan, T. (2011). An Estimated DSGE Model of the Jordanian Economy. IMF Working Paper, 11/28.

Svensson, L.E.0. (1999). Inflation targeting as a monetary policy rule. Journal of Monetary Economics, Volume 43, Issue 3, 607-654

Taylor, John B., (1993). Discretion versus Policy Rules in Practice,î CarnegieRochester Series on Public Policy 39, 195-214.Walsh, C. (2010). Monetary Theory and Policy. (3rd Edition). Cambridge Massachusets: MIT Press.

Tovar, E. C. (2008). DSGE models and central Banks. Bank for International Settlements. BIS Working Paper, No. 258.

Walsh, C. E. (2001). The Science (and Art) of Monetary Policy. Federal Reserve Bank of San Fransisco Economic Letter (May 4),13.

Walsh, C. E. (2010). Monetary Theory and Policy. (3rd Edition). Cambridge Massachusets: MIT Press.

Yüksel, C. (2013). Role of Investment Shocks in Explaining Business Cycles in Turkey. TCMB Working Paper, No:13/12.

Zimmermann, G. (2003). Optimal Monetary Policy : A New Keynesian View. The Quarterly Journal of Austrian Economics. Vol.6, No.4, 61-72 